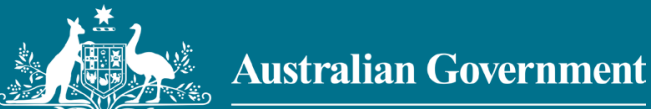

Geoscience Australia

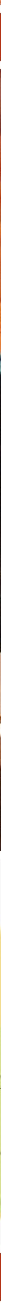

Record 2017/09 | eCat 110383

\title{
Spatial variations in lead isotopes, Tasman Element, eastern Australia
}

Huston, D. L., Champion, D. C., Morrison, G., Maas, R., Thorne, J. P., Carr, G., Beams, S., Bottrill, R., Chang, Z.-S.,

Dhnaram, C., Downes, P. M., Forster, D. B., Gemmell, J. B., Lisitsin, V., McNeill, A. and Vicary, M. 


\title{
Spatial variations in lead isotopes, Tasman Element, eastern Australia
}

\author{
GEOSCIENCE AUSTRALIA \\ RECORD 2017/09
}

D. L. Huston ${ }^{1}$, D. C. Champion ${ }^{1}$, G. Morrison ${ }^{2}$, R. Maas ${ }^{3}$, J. P. Thorne ${ }^{1}$, G. Carr ${ }^{4}$, S. Beams ${ }^{5}$, R. Bottrill $^{6}$, Z.-S. Chang ${ }^{7}$, C. Dhnaram ${ }^{8}$, P. M. Downes ${ }^{9}$, D. B. Forster ${ }^{9}$, J. B. Gemmell ${ }^{10}$, V. Lisitsin ${ }^{7}$, A. McNeill ${ }^{6}$, and M. Vicary ${ }^{6}$

\section{Australian Government}

Geoscience Australia

\footnotetext{
${ }^{1}$ Geoscience Australia, GPO Box 378, Canberra, ACT 2601

${ }^{2}$ Klondike Exploration Services, 7 Mary St., Townsville, QLD 4810

${ }^{3}$ School of Earth Sciences, University of Melbourne, Parkville, VIC 3010

${ }^{4}$ Commonwealth Scientific and Industrial Research Organisation

${ }^{5}$ Terra Search Pty Ltd, PO Box 981, Castletown, Hyde Park, Townsville, QLD 4812

${ }^{6}$ Mineral Resources Tasmania, PO Box 56, Rosny Park, TAS 7018

${ }^{7}$ Economic Geology Research Unit, James Cook University, Townsville, QLD 4811

${ }^{8}$ Geological Survey of Queensland, PO Box 15216, City East, QLD 4002

${ }^{9}$ Geological Survey of New South Wales, PO Box 344, Hunter Region Mail Centre, NSW 2310

${ }^{10}$ CODES, University of Tasmania, Private Bag 79, Hobart, TAS 7001
} 


\section{Department of Industry, Innovation and Science}

Minister for Resources and Northern Australia: Senator the Hon Matt Canavan

Assistant Minister for Industry, Innovation and Science: The Hon Craig Laundy MP

Secretary: Ms Glenys Beauchamp PSM

\section{Geoscience Australia}

Chief Executive Officer: Dr James Johnson

This paper is published with the permission of the CEO, Geoscience Australia

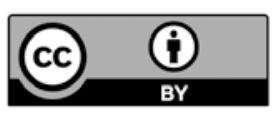

(c) Commonwealth of Australia (Geoscience Australia) 2017

With the exception of the Commonwealth Coat of Arms and where otherwise noted, this product is provided under a Creative Commons Attribution 4.0 International Licence.

(http://creativecommons.org/licenses/by/4.0/legalcode)

Geoscience Australia has tried to make the information in this product as accurate as possible. However, it does not guarantee that the information is totally accurate or complete. Therefore, you should not solely rely on this information when making a commercial decision.

Geoscience Australia is committed to providing web accessible content wherever possible. If you are having difficulties with accessing this document please email clientservices@ga.gov.au.

ISSN 2201-702X (PDF)

ISBN 978-1-925124-46-1 (PDF)

eCat 110383

Bibliographic reference: Huston, D. L., Champion, D. C., Morrison, G., Maas, R., Thorne, J. P., Carr, G., Beams, S., Bottrill, R., Chang, Z.-S., Dhnaram, C., Downes, P. M., Forster, D. B., Gemmell, J. B., Lisitsin, V., McNeill, A. and Vicary, M. 2017. Spatial variations in lead isotopes, Tasman Element, eastern Australia. Record 2017/09. Geoscience Australia, Canberra.

http://dx.doi.org/10.11636/Record.2017.009 


\section{Contents}

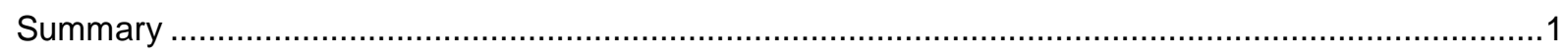

1 Introduction: radiogenic isotopes in tectonic and metallogenic studies ...........................................

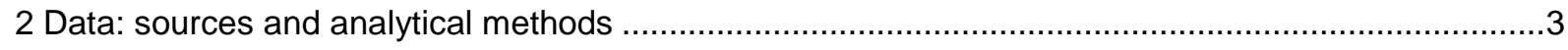

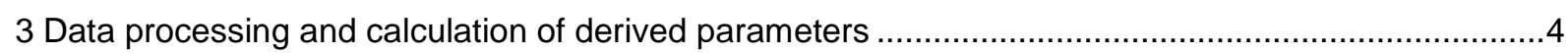

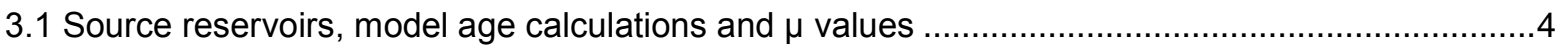

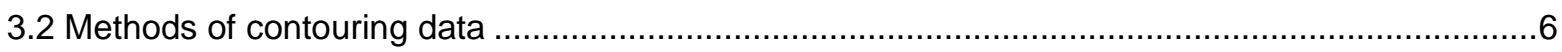

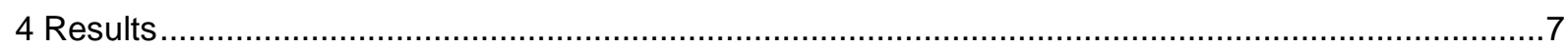

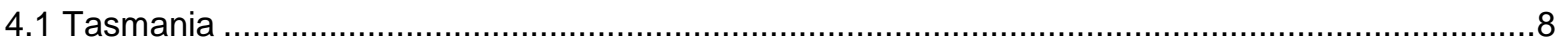

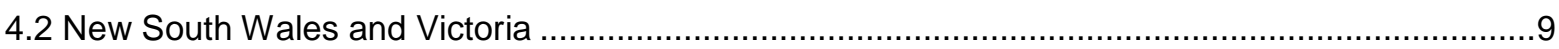

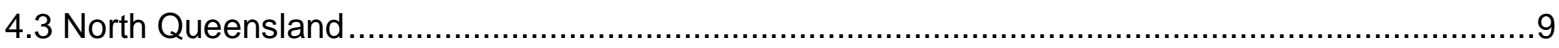

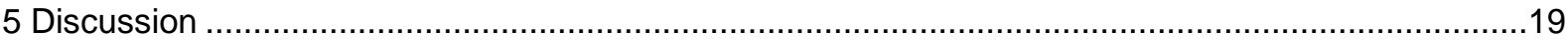

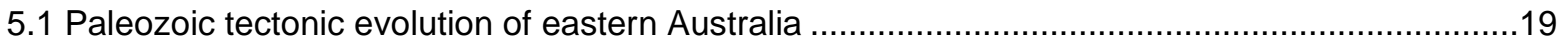

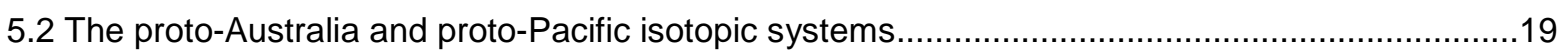

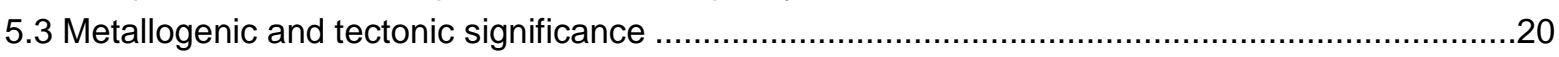

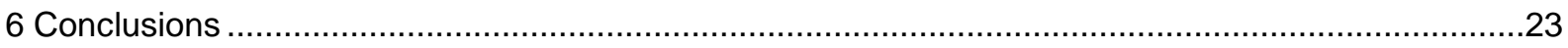

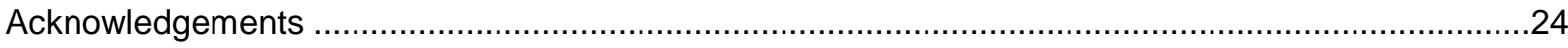

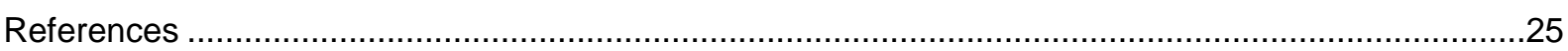

Appendix A Lead isotope data from the Tasman Element of eastern Australia...................................28

Appendix B Description of data included in lead isotope data from the Tasman Element of eastern Australia

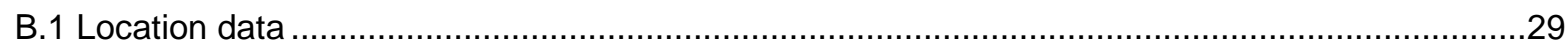

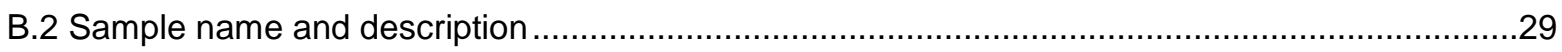

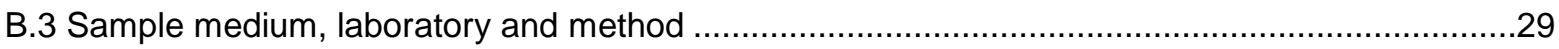

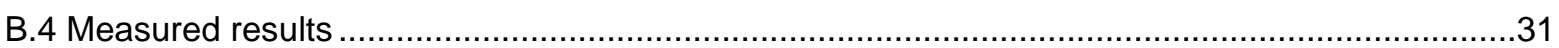

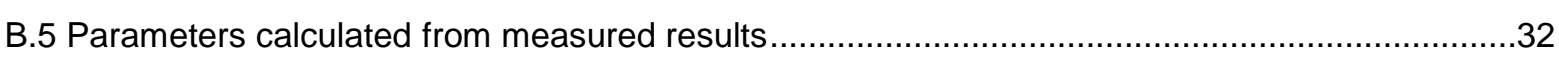

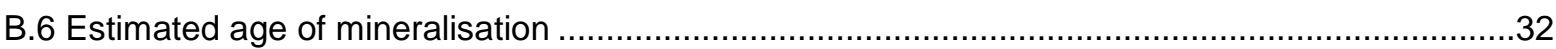

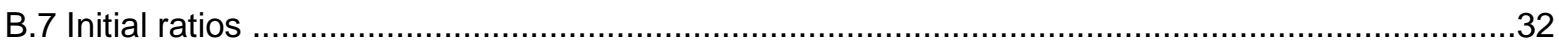

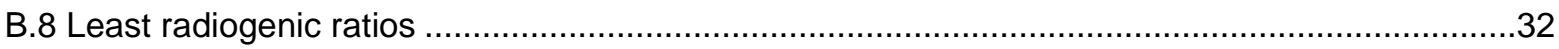

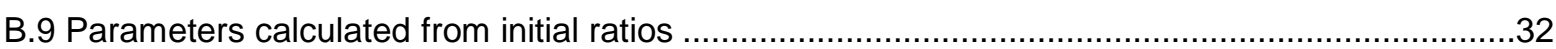

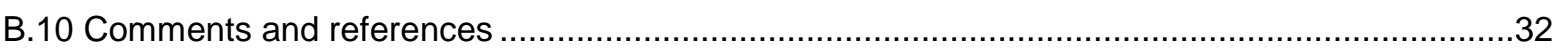




\section{Summary}

Lead isotope data from ore deposits and mineral occurrences in the Tasman Element of eastern Australia have been used to construct isotopic maps of this region. These maps exhibit systematic patterns in parameters derived from isotope ratios. The parameters include $\mu\left({ }^{238} \mathrm{U} /{ }^{204} \mathrm{~Pb}\right)$, as calculated using the Cumming and Richards (1975) lead evolution model, and the difference between true age of mineralisation and the Cumming and Richards lead isotope model age of mineralisation $(\Delta \mathrm{t})$.

Variations in $\mu$ coincide with boundaries at the orogen, subprovince and zone scales. The boundary between the Lachlan and New England orogens is accompanied by a decrease in $\mu$, and within the Lachlan Orogen, the Central Subprovince is characterised by $\mu$ that is significantly higher than in the adjacent Eastern and Western subprovinces. Within the Eastern Subprovince, the Cu-Au-rich Macquarie Arc is characterised by significantly lower $\mu$ relative to adjacent rocks.

The Macquarie Arc is also characterised by very high $\Delta t$ (generally above $200 \mathrm{Myr}$ ). Other regions characterised by very high $\Delta t$ include western Tasmania, the southeastern New England Orogen, and the Hodgkinson Province in northern Queensland. These anomalies are within a broad pattern of decreasing $\Delta t$ from east to west, with Paleozoic deposits within or adjacent to Proterozoic crust characterised by $\Delta t$ values of 50 Myr or below.

The patterns in $\Delta t$ are interpreted to reflect the presence of the two major tectonic components involved in the Paleozoic Tasman margin in Australia (cf., Münker, 2000): subducting proto-Pacific crust $(\Delta t>150 \mathrm{Myr})$, and Proterozoic Australia crust $(\Delta \mathrm{t}<50 \mathrm{Myr})$ on the over-riding plate. Proterozoic Australia crustal sources are interpreted to dominate the western parts of the Tasman Element and Proterozoic crust further to the west, whereas Pacific crustal sources are inferred to characterise western Tasmania and much of the eastern part of the Tasman Element. Contrasts in $\Delta t$ between the Cambrian Mount Read Volcanics in western Tasmania and similar aged rocks in western Victoria and New South Wales make direct tectonic correlation between these rocks problematic. 


\section{Introduction: radiogenic isotopes in tectonic and metallogenic studies}

It has been long established that radiogenic isotopes commonly reflect the tectonic makeup of crustal domains. For example, the Rb-Sr, Sm-Nd and U-Pb systems have been used to map the extent of Proterozoic crust in western North America (Kistler and Peterman, 1973; Bennett and DePaolo, 1987; Wooden and DeWitt, 1990). Similarly, Champion and Cassidy (2008) used Nd isotope model ages to map the distribution of major crustal boundaries as well as internal domains of relatively juvenile crust in the Archean Yilgarn Craton of Western Australia. Huston et al. (2014) have shown that Nd model age maps and analogous maps derived from $\mathrm{Pb}$ isotope data can be used to define more prospective zones for volcanic-hosted massive sulphide (juvenile isotopic zones) and komatiite-associated nickel sulphide deposits (more evolved isotopic zones) in Archean provinces. Champion (2013) used Nd data from granites and felsic volcanic rocks to create a national-scale Nd model age map for Australia, which images fundamental boundaries of crustal blocks that make up the continent. Champion and Huston (2016) discuss other Australian and global examples where radiogenic isotope distribution patterns have been related to metallogeny.

Huston et al. (2016a) demonstrated that parameters derived from lead isotope data can be used spatially to produce patterns that relate to known tectonic and metallogenic provinces in the Lachlan Orogen of New South Wales and Victoria. The purpose of this contribution is to extend the southeastern Australia study and produce a series of maps showing spatial variations in parameters derived from lead isotope data for the Tasman Element from southern Tasmania to Cape York in Queensland. These results are then compared with the results of Nd mapping and the distribution of known geological and metallogenic provinces. An ancillary result of this work is the compilation of a comprehensive dataset of lead isotope analyses from eastern Australia. This report is the first in a series of regional analyses leading ultimately to the compilation of a set of lead-isotope-derived maps for Australia that will complement the existing Nd model age map (Champion, 2013). 


\section{Data: sources and analytical methods}

The majority of lead isotope analyses used in this study were collected from the 1970s through the 2000s by the Commonwealth Scientific and Industrial Research Organisation (CSIRO) using conventional thermal ionisation mass spectrometry (TIMS). A much smaller number of analyses were also performed at CSIRO using double spike TIMS (DS-TIMS), which provides much more precise analyses. All these analyses have been supplemented by high precision analyses undertaken at the University of Melbourne in the last decade using multicollector inductively coupled plasma mass spectrometry (MC-ICP-MS), and by one analysis from the University of Alberta in Canada (also MCICP-MS). The data set was supplemented by a relatively small quantity of published data from other laboratories (Black and Richards, 1972: Australian National University using DS-TIMS; Ulrich et al., 2003: University of Queensland using MC-ICP-MS). The complete Pb isotope data set is listed in Appendix $\mathrm{A}$, detailing sample information (e.g., location, deposit) and $\mathrm{Pb}$ isotopic data (e.g., ${ }^{206} \mathrm{~Pb} /{ }^{204} \mathrm{~Pb},{ }^{207} \mathrm{~Pb} /{ }^{204} \mathrm{~Pb}$ and ${ }^{208} \mathrm{~Pb} /{ }^{204} \mathrm{~Pb}$ ratios). The database structure and metadata are described in Appendix B. Table 2.1 summarises long-term analytical uncertainties and error correlations (where available) for the CSIRO and the Universities of Melbourne and Alberta laboratories based on repeated analyses of international and internal standards.

Table 2.1 Analytical uncertainties and error correlations for laboratories that have produced data used in this study (based on long term repeat analyses of internal and international standards).

\begin{tabular}{|c|c|c|c|c|c|}
\hline$L a b$ & $\begin{array}{l}\text { Error }(2 \sigma): \\
\left.{ }^{206} \mathrm{~Pb}\right|^{204} \mathrm{~Pb}(\%)\end{array}$ & $\begin{array}{l}\text { Error (2б): } \\
{ }^{207} \mathrm{~Pb} /{ }^{204} \mathrm{~Pb}(\%)\end{array}$ & $\begin{array}{l}\text { Error }(2 \sigma) \\
{ }^{208} \mathrm{~Pb} /{ }^{204} \mathrm{~Pb}(\%)\end{array}$ & $\begin{array}{l}\text { Error correlation: } \\
\rho_{207 / 204-206 / 204}\end{array}$ & $\begin{array}{l}\text { Error correlation: } \\
\rho_{208 / 204-206 / 204}\end{array}$ \\
\hline $\begin{array}{l}\text { CSIRO } \\
\text { (conventional } \\
\text { TIMS) }\end{array}$ & 0.1 & 0.05 & 0.1 & $\mathrm{~N} / \mathrm{A}$ & N/A \\
\hline $\begin{array}{l}\text { CSIRO (double } \\
\text { spike TIMS) }\end{array}$ & 0.01 & 0.01 & N/A & $N / A$ & N/A \\
\hline $\begin{array}{l}\text { University of } \\
\text { Alberta (MC- } \\
\text { ICP-MS) }\end{array}$ & 0.032 & 0.028 & 0.034 & $\mathrm{~N} / \mathrm{A}$ & N/A \\
\hline $\begin{array}{l}\text { University of } \\
\text { Melbourne (MC- } \\
\text { ICP-MS) }\end{array}$ & 0.015 & 0.019 & 0.027 & 0.84 & 0.73 \\
\hline
\end{tabular}

In addition to the lead isotope ratios, some samples were also analysed for ${ }^{238} \mathrm{U}$ and ${ }^{232} \mathrm{Th}$ using isotope dilution methods, and these results are also summarised in Appendix A. Where individual samples were analysed multiple times, the results were averaged to produce a single analysis. In these cases, the number of separate analyses used to calculate the average is noted in comments in Appendix A. 


\section{Data processing and calculation of derived parameters}

Measured lead isotope ratios $\left({ }^{206} \mathrm{~Pb} /{ }^{204} \mathrm{~Pb},{ }^{207} \mathrm{~Pb} /{ }^{204} \mathrm{~Pb}\right.$ and ${ }^{208} \mathrm{~Pb} /{ }^{204} \mathrm{~Pb}$ ratios) of ore samples reflect a number of different processes that occurred during and after crystallisation of the host mineral or rock. When the mineral/rock initially crystallises, the incorporated lead will be characterised by isotopic ratios that reflect those of the source lead reservoir at the time of crystallisation. These ratios are termed initial ratios. In a closed chemical system, these initial ratios change over time through the ingrowth of radiogenic lead isotopes ${ }^{206} \mathrm{~Pb},{ }^{207} \mathrm{~Pb}$ and ${ }^{208} \mathrm{~Pb}$, produced by the radioactive decay of ${ }^{238} \mathrm{U}$, ${ }^{235} \mathrm{U}$ and ${ }^{232} \mathrm{Th}$, respectively, trapped within the host. In minerals where the concentration of lead greatly exceeds those of uranium and thorium, the growth of the radiogenic isotopes is insignificant relative to the initial amount of these isotopes present in the measured sample. In such minerals there is very little change in the ${ }^{206} \mathrm{~Pb} /{ }^{204} \mathrm{~Pb},{ }^{207} \mathrm{~Pb} /{ }^{204} \mathrm{~Pb}$ and ${ }^{208} \mathrm{~Pb} /{ }^{204} \mathrm{~Pb}$ ratios with time, and the current-day measured ratios closely approximate, and can be used as a measure of, initial isotopic ratios. This approximation is valid for galena and other $\mathrm{Pb}$-rich samples unless accompanied by extremely high uranium (and/or thorium) contents. For practical purposes we considered a sample to be lead-rich if the concentration of lead exceeds $1000 \mathrm{ppm}$. For these samples, the measured ratios are assumed to approximate the initial ratios, and are reported and used in subsequent calculations as such.

For rocks/minerals with significant amounts of thorium and uranium that remained chemically closed after crystallisation, initial ratios can be estimated using the measured lead isotope ratios, and the measured ${ }^{238} \mathrm{U} /{ }^{204} \mathrm{~Pb}$ and ${ }^{232} \mathrm{Th} /{ }^{204} \mathrm{~Pb}$ ratios with the following equations:

$$
\begin{aligned}
& \left({ }^{206} \mathrm{~Pb} /{ }^{204} \mathrm{~Pb}\right)_{i}=\left({ }^{206} \mathrm{~Pb} /{ }^{204} \mathrm{~Pb}\right)_{\mathrm{s}}-\left({ }^{238} \mathrm{U} /{ }^{204} \mathrm{~Pb}\right)_{\mathrm{s}}\left(\mathrm{e}^{\lambda_{238^{\mathrm{t}}}}-1\right) \\
& \left.\left({ }^{207} \mathrm{~Pb} /{ }^{204} \mathrm{~Pb}\right)_{\mathrm{i}}=\left({ }^{207} \mathrm{~Pb} /{ }^{204} \mathrm{~Pb}\right)_{\mathrm{s}}-\left({ }^{238} \mathrm{U} /{ }^{204} \mathrm{~Pb}\right)_{\mathrm{s}} / 137.88\right)\left(\mathrm{e}^{\lambda_{235^{\mathrm{t}}}}-1\right) \\
& \left({ }^{208} \mathrm{~Pb} /{ }^{204} \mathrm{~Pb}\right)_{\mathrm{i}}=\left({ }^{208} \mathrm{~Pb} /{ }^{204} \mathrm{~Pb}\right)_{\mathrm{s}}-\left({ }^{232} \mathrm{Th} /{ }^{204} \mathrm{~Pb}\right)_{\mathrm{s}}\left(\mathrm{e}^{\lambda_{232} \mathrm{t}_{\mathrm{f}}}-1\right)
\end{aligned}
$$

where the subscripts (i) and (s), associated with the isotopic ratios, indicate initial and measured values, respectively; $\lambda_{238}, \lambda_{235}$, and $\lambda_{232}$ are the ${ }^{238} \mathrm{U},{ }^{235} \mathrm{U}$ and ${ }^{232} \mathrm{Th}$ decay constants (Table 3.1), respectively; and $\mathrm{t}_{\mathrm{f}}$ is the crystallisation or formation age (in Myr).

Use of these equations assumes a closed chemical system after crystallisation of the host. However, post-crystallisation processes, such as recrystallisation during metamorphism or weathering can open the chemical system leading to loss (or, in some cases, gain) of lead, uranium and/or thorium. If the system opened and then closed shortly after crystallisation of the host, this effect is commonly minimal.

\subsection{Source reservoirs, model age calculations and $\mu$ values}

For a given closed lead source reservoir, the evolution of lead isotopic ratios is determined by the original ratios at the time the reservoir formed, by the relative lead, uranium and thorium concentrations of the reservoir, and by time. With increasing time, ${ }^{206} \mathrm{~Pb},{ }^{207} \mathrm{~Pb}$ and ${ }^{208} \mathrm{~Pb}$ grow by 
radioactive decay of ${ }^{238} \mathrm{U},{ }^{235} \mathrm{U}$ and ${ }^{232} \mathrm{Th}$, respectively. If the original characteristics of the source reservoir can be determined, the evolution of lead in the reservoir can be modelled. There are two global, and a wide range of regional, models that model lead isotope growth of lead reservoirs. These models produce 'model ages', which are ages that date the extraction of lead from the reservoir. In some cases, model ages can accurately reflect the age of mineralisation. However, it must be stressed that only regionally or locally-constrained models, that is those constructed by fitting the evolution model to local data, consistently produce reliable model ages. As discussed below, quite different lead sources can be located adjacent to each other, producing complicated lead isotope ratio patterns in relatively small regions.

Table 3.1 Half-lives and decay constants of the U-Th-Pb isotopic system (data from Dickin (1995)).

\begin{tabular}{|l|c|c|c|c|}
\hline & & & & \\
\hline Isotopic system & Parent isotope & Daughter isotope & $t^{1 / 2}(\mathrm{Ga})$ & $\lambda\left(\mathbf{s}^{-1}\right)$ \\
\hline $\mathrm{U}-\mathrm{Pb}$ & ${ }^{238} \mathrm{U}$ & ${ }^{206} \mathrm{~Pb}$ & 4.47 & $1.55125 \times 10^{-10}$ \\
\hline $\mathrm{U}-\mathrm{Pb}$ & ${ }^{235} \mathrm{U}$ & ${ }^{207} \mathrm{~Pb}$ & 0.704 & $9.8485 \times 10^{-10}$ \\
\hline $\mathrm{Th}-\mathrm{Pb}$ & ${ }^{232} \mathrm{Th}$ & ${ }^{208} \mathrm{~Pb}$ & 14.01 & $0.49475 \times 10^{-10}$ \\
\hline
\end{tabular}

In addition to model ages, lead evolution models also model U/Pb ratios, typically synthesised as ${ }^{238} \mathrm{U} /{ }^{204} \mathrm{~Pb}$ (integrated to present day; also known as mu $(\mu)$ ). Like $\varepsilon_{\mathrm{Nd}}$, this parameter can be used in a broad sense to infer how juvenile or evolved the lead source reservoir was. Again it must be stressed that both model ages and $\mu$ depend upon the model used. Different models give different model ages and $\mu$ for the same samples, although relative differences between samples for these parameters are similar and independent of the model used.

There are two well-established global lead isotope evolution models (Cumming and Richards, 1975; Stacey and Kramers, 1975). The Cumming and Richards (1975) model is most appropriate to the Tasman Element of Australia as it was partially established using data for Captains Flat and CSA mines (Lachlan Orogen) and Halls Peak deposit (New England Orogen) in New South Wales. For each lead isotope sample in Appendix $A$, model ages and $\mu$ were calculated using the Cumming and Richards (1975) model. Variations in $\mu$ as a function of model age were calculated using the ${ }^{238} \mathrm{U} \rightarrow$ ${ }^{206} \mathrm{~Pb}$ and ${ }^{235} \mathrm{U} \rightarrow{ }^{207} \mathrm{~Pb}$ decay chains, as follows (Cumming and Richards, 1975; S.-S. Sun, pers. comm., 2004):

$$
\begin{aligned}
& \mu_{238}=\left(\left({ }^{206} \mathrm{~Pb} /{ }^{204} \mathrm{~Pb}\right)_{\mathrm{s}}-\mathrm{A}_{0}\right) /\left(\mathrm{e}^{4.509 \lambda_{238}}\left(1-\varepsilon\left(4.509-1 / \lambda_{238}\right)\right)-\mathrm{e}^{\mathrm{t}_{\mathrm{m}} \lambda_{238}}\left(1-\varepsilon\left(\mathrm{t}_{\mathrm{m}}-1 / \lambda_{238}\right)\right)\right) \\
& \mu_{235}=137.88\left(\left({ }^{207} \mathrm{~Pb} /{ }^{204} \mathrm{~Pb}\right)_{\mathrm{s}}-\mathrm{B}_{0}\right) /\left(\mathrm{e}^{4.509 \lambda_{235}}\left(1-\varepsilon\left(4.509-1 / \lambda_{235}\right)\right)-\mathrm{e}^{\left.\mathrm{t}_{\mathrm{m}} \lambda_{235}\left(1-\varepsilon\left(\mathrm{t}_{\mathrm{m}}-1 / \lambda_{235}\right)\right)\right)}\right.
\end{aligned}
$$

where $\mathrm{A}_{0}$ and $\mathrm{B}_{0}$ are the estimated initial ${ }^{206} \mathrm{~Pb} /{ }^{204} \mathrm{~Pb}$ and ${ }^{207} \mathrm{~Pb} /{ }^{204} \mathrm{~Pb}$ of Earth (at $4.509 \mathrm{Ga}$ ), $\mu_{238}$ and $\mu_{235}$ are representatives of $\mu$ based on the ${ }^{238} U$ and ${ }^{235} U$ decay chains, respectively; $\left({ }^{206} \mathrm{~Pb} /{ }^{204} \mathrm{~Pb}\right){ }_{\mathrm{s}}$ and $\left({ }^{207} \mathrm{~Pb} /{ }^{204} \mathrm{~Pb}\right)_{\mathrm{s}}$ are measured ratios of the sample; $\lambda_{238}$ and $\lambda_{235}$ are decay constants for ${ }^{238} \mathrm{U}$ and ${ }^{235} \mathrm{U}$, respectively (Table 3.1); $\varepsilon$ is the Cumming and Richards (1975) rate factor $\left(0.050 \times 10^{-9} \mathrm{yr}^{-1}\right.$ for this model) for a continuous change in ${ }^{235} \mathrm{U} /{ }^{204} \mathrm{~Pb}$ with time; and $\mathrm{t}_{\mathrm{m}}$ is the model age.

Equations (4) and (5) are calculated iteratively modifying $t_{m}$ until $\mu$ converges (achieved when $\mid \mu_{238}$ $\mu_{235} \mid<0.0015$ ), yielding the final model age and $\mu$ value. These parameters were calculated for all analyses, and for each deposit/prospect the analysis that yielded the oldest model age was selected as least radiogenic. Importantly, we have found that in most cases $\mu$ does not change significantly, even during radiogenic ingrowth following mineral/rock crystallisation. Hence, all least radiogenic data 
points were used to construct interpolated maps showing regional variations in calculated $\mu$. Critically the interpolated regional maps produced from the Cumming and Richards (1975) $\mu$ calculations are similar in pattern to those produced using other lead-isotope-derived parameters (e.g., Stacey and Kramers (1975) $\mu$ and the Lachlan lead index (cf. Huston et al., 2016a)). Accordingly, these other parameters are not considered further.

For approximately $68 \%$ of the deposits/prospects for which lead isotope data are available, initial ratios can be established either from $\mathrm{Pb}$-rich samples, or for $\mathrm{Pb}$-poor samples by back-calculation where $\left({ }^{238} \mathrm{U} /{ }^{204} \mathrm{~Pb}\right)_{\mathrm{s}},\left({ }^{232} \mathrm{Th} /{ }^{206} \mathrm{~Pb}\right)_{\mathrm{s}}$ and mineralisation age data are available. For many of the deposits/prospects for which initial ratios are available, actual mineralisation ages are known or can be reliably inferred. Appendix A also includes estimates of mineralisation ages based upon independent age determinations (cf. Huston et al., 2016b) or inferred from regional associations.

Formation and model ages (estimated from least radiogenic initial ratios) for 401 deposits were combined as a second parameter, $\Delta \mathrm{t}$, defined as follows:

$$
\Delta \mathrm{t}=\mathrm{t}_{\text {mineralisation }}-\mathrm{t}_{\text {model }}
$$

As with the $\mu$ maps, patterns established using model ages from other evolution models (e.g., Stacey and Kramers, 1975) produce similar patterns although with different absolute values for $\Delta t$. Hence, only Cumming and Richards (1975) $\Delta t$ maps are presented herein. Another important result is the range in $\Delta t$ is very large ( $\sim 600$ million years (Myr), excluding outliers), so small to moderate errors in formation age estimates (e.g. 50-100 Myr or less) do not affect the resulting patterns substantially.

\subsection{Methods of contouring data}

The approach used here to contour data follows that of Champion (2013) who found that natural neighbour classification using natural breaks in data values (as against equal intervals or equal counts) worked well. Gridding performed in ArcMap $^{\mathrm{TM}}$ was undertaken using Natural Neighbour Interpolation with intervals based on natural breaks. The natural breaks techniques used by ArcMap ${ }^{\mathrm{TM}}$ follows the Jenks optimisation method - also known as the goodness of variance fit - which identifies thresholds that optimise (i.e., minimise) the sum of squared deviations of interval means. Slocum et al. (2009) have discussed the relative merits of different data classification procedures. 


\section{Results}

Figure 4.1A and B illustrate variations in $\mu$ and $\Delta t$, respectively, based on Cumming and Richards (1975), and Figure 4.2 shows variations in two stage depleted mantle Nd model ages derived after Champion (2013) for the Tasman Element as a whole. In most, if not all cases, the variations seen in the two derived $\mathrm{Pb}$ isotope parameters do not reflect variations in the age and/or style of deposits, as most of the features shown in Figure 4.1 are defined using data from deposits with different origin and age, and in most areas with multiple deposit types, the different deposit types had similar $\mu$ and $\Delta t$ values (see discussion of Zeehan district in section 4.1 for an exception).

Variations in $\mu$ (Figure 4.1A) reflect a number of crustal block boundaries, including that between the Lachlan and New England orogens. The Lachlan Orogen is characterised overall by higher $\mu$ than the New England Orogen, a feature also reflected in Nd data (Champion, 2013; Figure 4.2). A boundary between the Lachlan and Thomson orogens is not obvious in the current data, which is very limited in the Thomson Orogen. Like the Lachlan lead index (Huston et al., 2016a), variations in $\mu$ map the boundary between the Eastern (low to intermediate $\mu$ ) and Central Lachlan (high $\mu$ ), and define the Canberra (moderate to high $\mu$ ) and Parkes (low to moderate $\mu$ ) domains (originally defined using the Lachlan lead index) reasonably well.

The Tasman Element map identifies a number of distinct regional areas of low $\mu$, which indicate the presence of juvenile lead sources. The best-defined area is associated with the Macquarie Arc, a feature also identified using the Lachlan lead index. The New England Orogen is also relatively juvenile, particularly in northeastern NSW, where the data define an annulus of juvenile lead around a central zone of more evolved $\mathrm{Pb}$ - this pattern corresponds with a similar one present in the $\mathrm{Nd}$ isotope data (Champion, 2013: Figure 4.2). There is also a zone of lower $\mu$ in central Queensland that corresponds to the Mount Morgan-Mount Chalmers area (deposit locations not shown), an area also characterised as juvenile using $\mathrm{Nd}$ isotope data (Figure 4.2). In addition to these main zones of low $\mu$, there are also some more local zones described in Sections 4.2 and 4.3. Tasmania is characterised by intermediate values in $\mu$ and a limited range compared to other parts of the Tasman Element (although patterns are apparent when the data are looked at in more detail: section 4.3).

Variations in $\Delta t$ are also apparent at the scale of the Tasman Element (Figure 4.1B). The most striking observation is that the West Tasmania Terrane is characterised by high values of $\Delta t$ ( $>170 \mathrm{Myr}$ ) in stark contrast to most of the Lachlan Orogen. The $\Delta t$ data suggests that (western) Tasmania is characterised by crust that has seen long-term accelerated lead growth through radioactive decay compared to much of the rest of eastern Australia. These results are not compatible with simple correlation of Cambrian rocks in the Mount Read Volcanics with those in western Victoria (Mount Stavely Volcanic Complex) and New South Wales (Koonenberry Province). High $\Delta$ t values also characterise the Macquarie Arc, and to a lesser, but less well defined, extent, the southeastern New England Orogen and the Hodgkinson Province in the Mossman Orogen in north Queensland (see also Sections 4.2 and 4.3 ).

Much of the Lachlan Orogen is characterised by crust that is well modelled by the Cumming and Richards (1975) model (i.e., with $\Delta t$ around -50 to $+100 \mathrm{Myr}$ ). The western parts of this orogen are characterised by lower $\Delta t$ values. Another region with low $\Delta t$ values is the Proterozoic margin in northern Queensland (section 4.3). These data suggest a strong Proterozoic influence on lead sources through much of the western part of the Tasman Element. The only part of Tasmania 
characterised by low $\Delta t$ values is the far northeastern corner, which is characterised by $\Delta t$ values of between $-55 \mathrm{Myr}$ and $75 \mathrm{Myr}(\mathrm{n}=3)$. These results are compatible with tectonic interpretations that the East Tasmania Terrane is an extension of the Lachlan Orogen (Glen, 2013).

The spatial variations present in $\Delta t$ are highlighted by comparing histograms for this parameter on a State-by-State basis (Figure 4.3). The overall distribution suggests two major modes of $\Delta t$ centred on $200 \mathrm{Myr}$ (250 to $150 \mathrm{Myr}$ ) and $0 \mathrm{Myr}$ (50 to $-50 \mathrm{Myr}$ ), with a very sparse scattering of data below -250 Myr. When outliers are excluded and the data are separated by State, Tasmania dominates the 200 Myr mode (with a small contribution from the Macquarie Arc in NSW), while the 0 Myr mode is largely within New South Wales, Victoria and South Australia. In Queensland there is a significant component in Qld of $\Delta t$ values around $200 \mathrm{Myr}$, although these are skewed to slightly less positive values (between 150 and $200 \mathrm{Myr}$ ). These largely correspond to samples within the southeastern New England Orogen and Hodgkinson Province (Mossman Orogen). The few values below -100 Myr are largely restricted to Paleozoic deposits hosted by Proterozoic rocks in the Proterozoic Etheridge and Croydon Provinces in Queensland (in North Australian Element).

\subsection{Tasmania}

As discussed above, Tasmania has the lowest variability in $\mu$ of any state, with a total range of only $\sim 0.1$ units as compared to a range of $\sim 0.4$ units for the entire Tasman Element. Despite the narrow range in values, which is approaching the uncertainty associated with estimating $\mu$, the data seem to define relatively clear patterns (Figure 4.4A). The mapping identifies three zones of relatively low $\mu$ $(<10.66)$ : (1) a north-northwest -trending zone along the west coast, (2) an east-west-trending zone in the north central part of the State, and (3) a northeast-treding zone between these other two zones. Zones (2) and (3) are associated with the main part of the highly mineralised Mount Read Volcanic Belt. A fourth zone, defined by one data point, is located in the southeastern part of the State. The mapping also defines a zone of higher $\mu$ that partly wraps zone (3). The highest $\mu$ value is from the Forster prospect in southern Tasmania (location not shown). The zone associated with this analysis is possibly overstated as there are no nearby analyses to constrain it. The geological significance, if any, of these zones is unclear.

With the exception of an area of relatively low $\Delta t$ to the west of Queenstown, there is a reasonably well defined zonation in western Tasmania of increasing $\Delta t$ from southeast to northwest (from the Tyennan Nucleus to the Rocky Cape Block (Figure 4.4B). This pattern is similar to that determined by contouring ${ }^{206} \mathrm{~Pb} /{ }^{204} \mathrm{~Pb}$ of Cambrian deposits (Figure 4.5B; constructed from original data from CSIRO and not including new data) and, to a lesser extent, of Devonian deposits (not shown). Not only do these maps show the southeast to northwest gradient, a north-trending linear zone is present in both the $\Delta \mathrm{t}$ and Cambrian ${ }^{206} \mathrm{~Pb} /{ }^{204} \mathrm{~Pb}$ maps. The two largest deposits in the Mount Read Volcanics (Mount Lyell (located just to the east of Queenstown) and Rosebery are located on or near this linear zone (Fig. 4.6B).

In the Devonian ( $360 \mathrm{Ma}$ ) Zeehan field (for location see Figure 4.4), ${ }^{206} \mathrm{~Pb} /{ }^{204} \mathrm{~Pb}$ data (Figure 4.6) define a district-scale zonation centred on the high-temperature Queen Hill tin deposit and a protuberance of the buried Heemskirk Granite (high ${ }^{206} \mathrm{~Pb} /{ }^{204} \mathrm{~Pb}$ ) that grades outward to lower temperature fissure style $\mathrm{Pb}-\mathrm{Ag}-\mathrm{Zn}$ veins (lower ${ }^{206} \mathrm{~Pb} /{ }^{204} \mathrm{~Pb}$ : e.g., Comstock and Montana mines). This relationship suggests the input of more radiogenic granite-related lead into a rock package dominated by less radiogenic lead. This pattern suggests that lead isotope ratios and derived parameters can be used as vectors to ore in granite-related systems. 


\subsection{New South Wales and Victoria}

Although the broad trends in both $\mu$ and $\Delta t$ in the Phanerozoic of New South Wales and Victoria have been discussed earlier, there are local variations in these parameters that merit further discussion (Figure 4.7). For example, there are a number of small areas that have low $\mu$, although most are based on only a small number of analyses. Of these, perhaps most confidence can be attached to zones in the Koonenberry Province (northwestern New South Wales) and in the westernmost part of the Stawell Zone (western Victoria).

Patterns in $\mu$ from the Koonenberry Province indicate local interplay between juvenile and more evolved lead sources. This pattern is consistent with the interpretation by Greenfield et al. (2010, 2011) that much of the Koonenberry Province developed on the over-riding plate of a middle Cambrian west-dipping subduction zone, with the associated development of magmatic arcs and back-arc basins. The present density of data, however, is insufficient to allow resolution of details.

The other low- $\mu$ zone of possible significance is located in the very western part of the Stawell Zone. The steep gradient to higher $\mu$ to the west in the Grampians-Stavely Zone coincides with the Moyston Fault, a fundamental tectonic boundary in western Victoria (Birch and Vandenberg, 2003). The zone of low $\mu$ appears to correspond to the distribution of the Magdala Basalt and correlated mafic volcanic rocks, which are interpreted as tholeiitic by Crawford et al. (2003). The presence of isolated low $\mu$ zones to the east, in central Victoria, may also reflect the presence of tholeiitic volcanics (Fig. 4.7B).

As discussed above, Phanerozoic rocks of western New South Wales and Victoria are characterised by negative $\Delta t$ values, possibly reflecting the influence of Proterozoic Australian crust (or sediments derived from them). A reasonably well-defined zone of similar moderately negative $\Delta t$ values is also present in eastern New South Wales and broadly corresponds to the Silurian Goulburn Basin, an extensional basin that contains a series of volcanic-hosted massive sulphide deposits.

\subsection{North Queensland}

Figure 4.8 shows variations in $\mu$ and $\Delta t$ for northeastern Queensland. The most striking feature of the $\mu$ map is the presence of two zones, one with low $\mu$ and the second with high $\mu$ (indicated by arrows on Figure 4.8A). These zones, however, are based upon single analyses, and, therefore, their significance is questionable. The low $\mu$ anomaly (blue arrow) is probably real as is coincides closely with a primitive Nd isotopic zone (Figure 4.9; Champion, 2013) marking the presence of very juvenile mafic granites in that area. It also is consistent with geological interpretations for the region which have identified remnants of an oceanic arc (Henderson et al., 2013). For these reasons the low $\mu$ zone is likely to be real but it is unlikely to be as extensive as indicated in Figure 4.8A (the size indicated from Nd data in Figure 4.9 is more realistic as it is based on multiple analyses). The large size of the low $\mu$ zone reflects the lack of data points to the southeast to constraint the interpretation, evidenced by the apparent anomaly crossing the boundary between the Thomson and Mossman orogens. The significance of the high $\mu$ zone (red arrow) to the northwest is particularly questionable as it is defined by one sample with a $\mu$ value significantly higher than samples from nearby Phanerozoic deposits hosted by Proterozoic rocks which have lower and relatively uniform $\mu$ values. Variations in $\Delta t$ are more interesting (Figure 4.8B). Based on data only from Paleozoic deposits, there is a strong gradient between the Proterozoic Etheridge Province (North Australian Element) and the Paleozoic Hodgkinson Province (Mossman Orogen). Deposits in the Etheridge Province are characterised by strongly negative $\Delta t$, whereas the Hodgkinson Province has very positive values approaching those of the Mount Read Volcanics and the Macquarie Arc (Sections 4.1 and 4.2). This suggests that the lead source in Proterozoic basement rocks in northeastern Queensland differs from that in the adjacent 


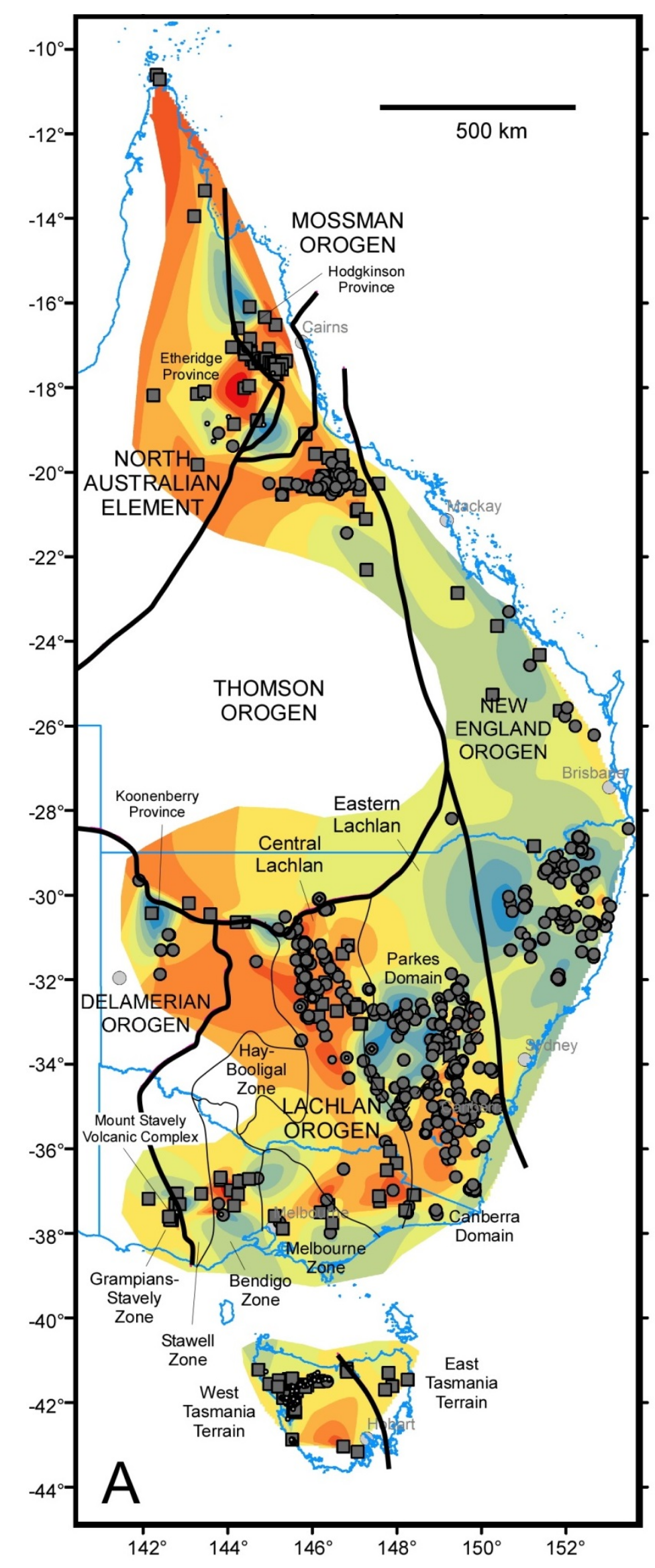

\begin{tabular}{|c|}
\hline Legend \\
\hline Sample sites and precision \\
\hline 口 High precision \\
\hline - Low precision, QF 0-4 \\
\hline - Low precision, QF 5-7 \\
\hline - Low precision, QF 8-9 \\
\hline - Low precision, QF NA \\
\hline$\mu$ (measured) \\
\hline$<10.49$ \\
\hline $10.49-10.57$ \\
\hline $10.57-10.62$ \\
\hline $10.62-10.65$ \\
\hline $10.65-10.68$ \\
\hline $10.68-10.71$ \\
\hline $10.71-10.74$ \\
\hline $10.74-10.77$ \\
\hline $10.77-10.86$ \\
\hline$>10.86$ \\
\hline $\begin{array}{l}\text { Boundaries } \\
\text { Orogen } \\
\text { Province-Zone }\end{array}$ \\
\hline
\end{tabular}

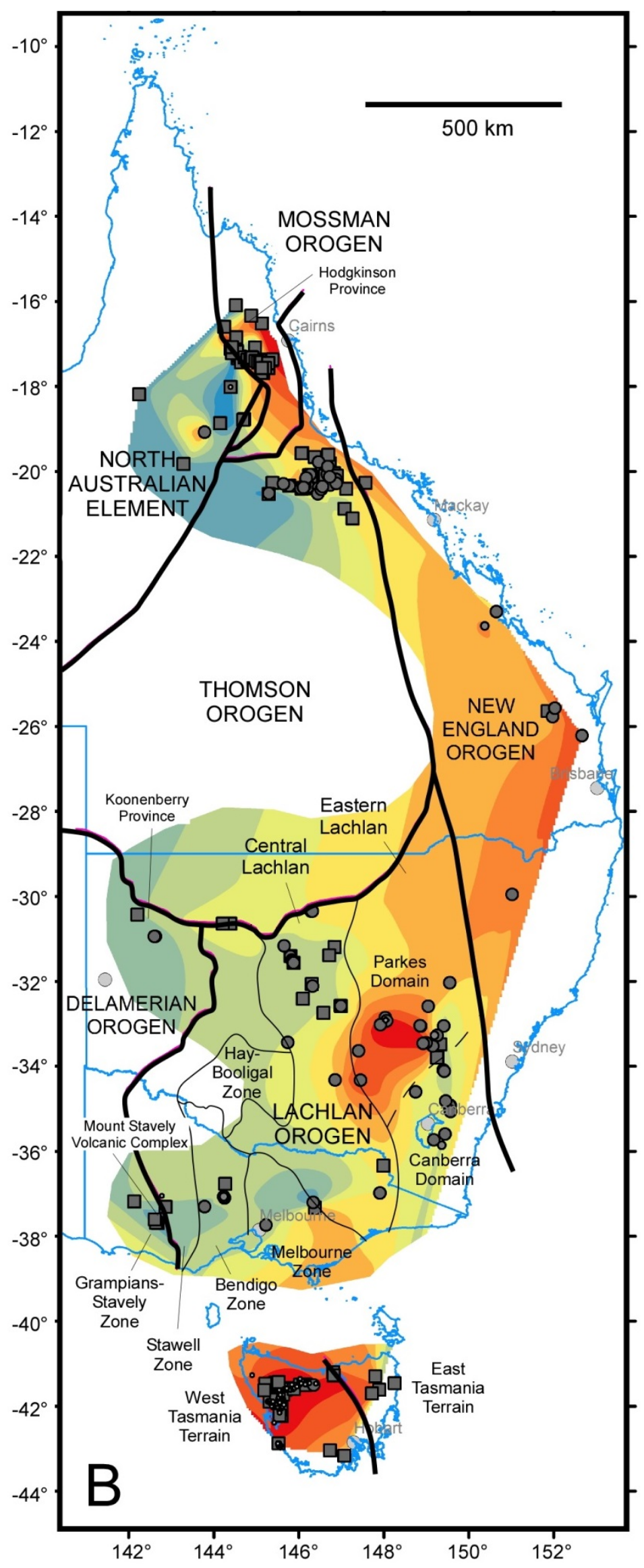

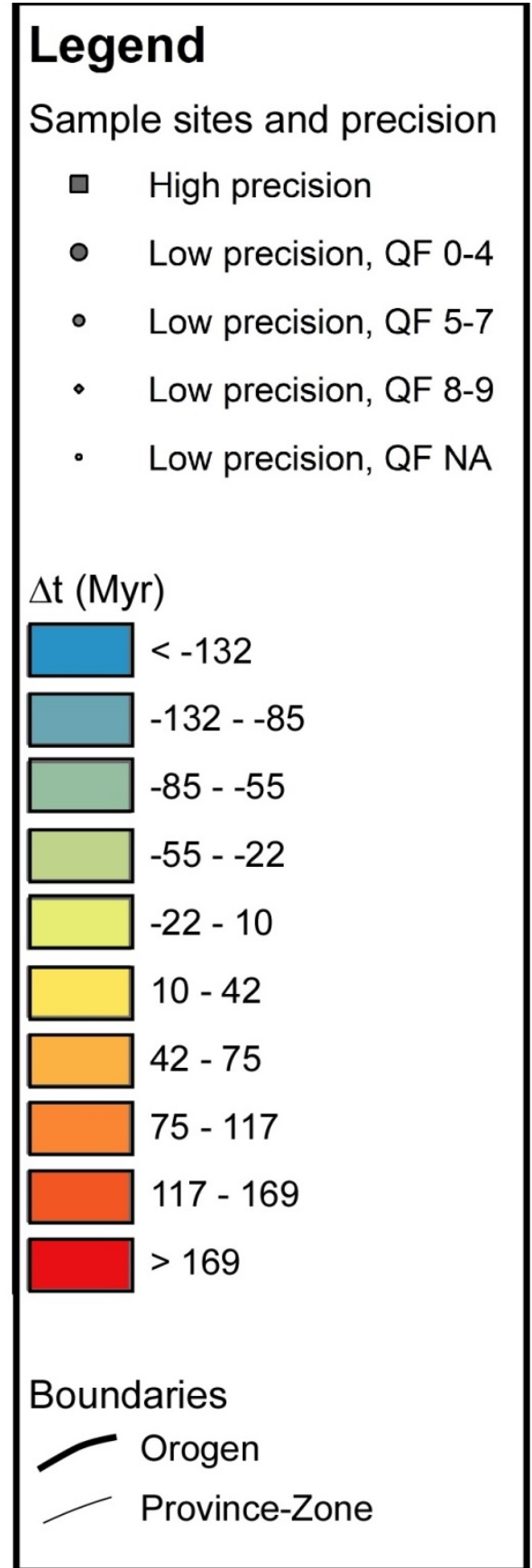

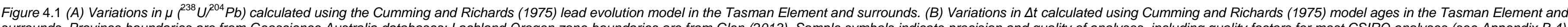

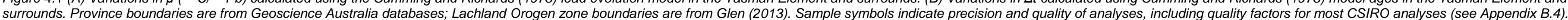



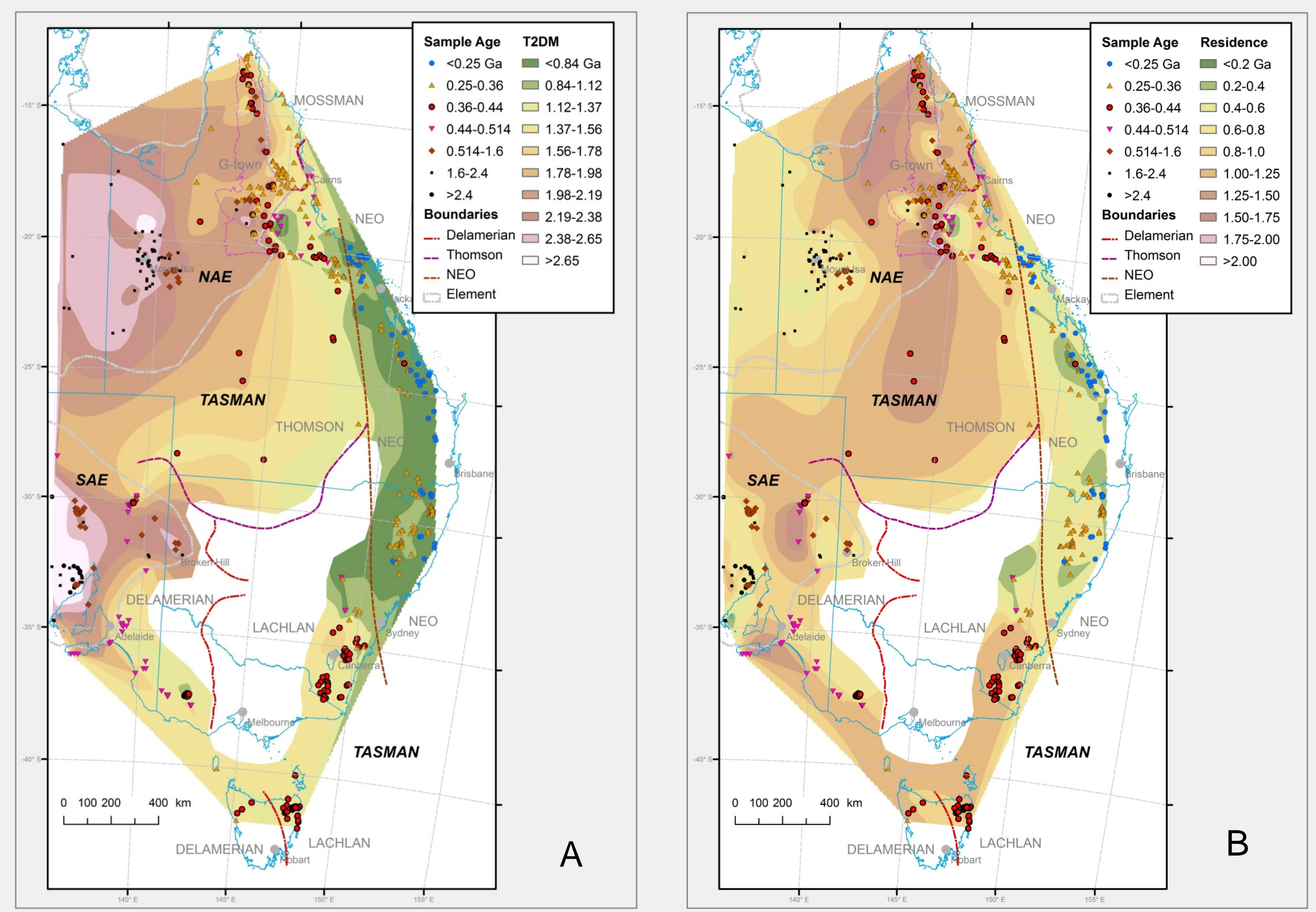

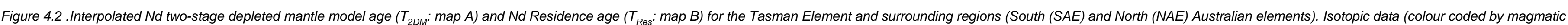

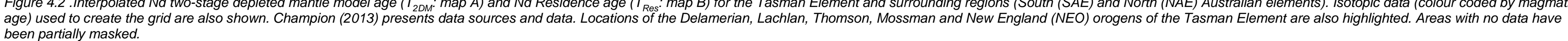



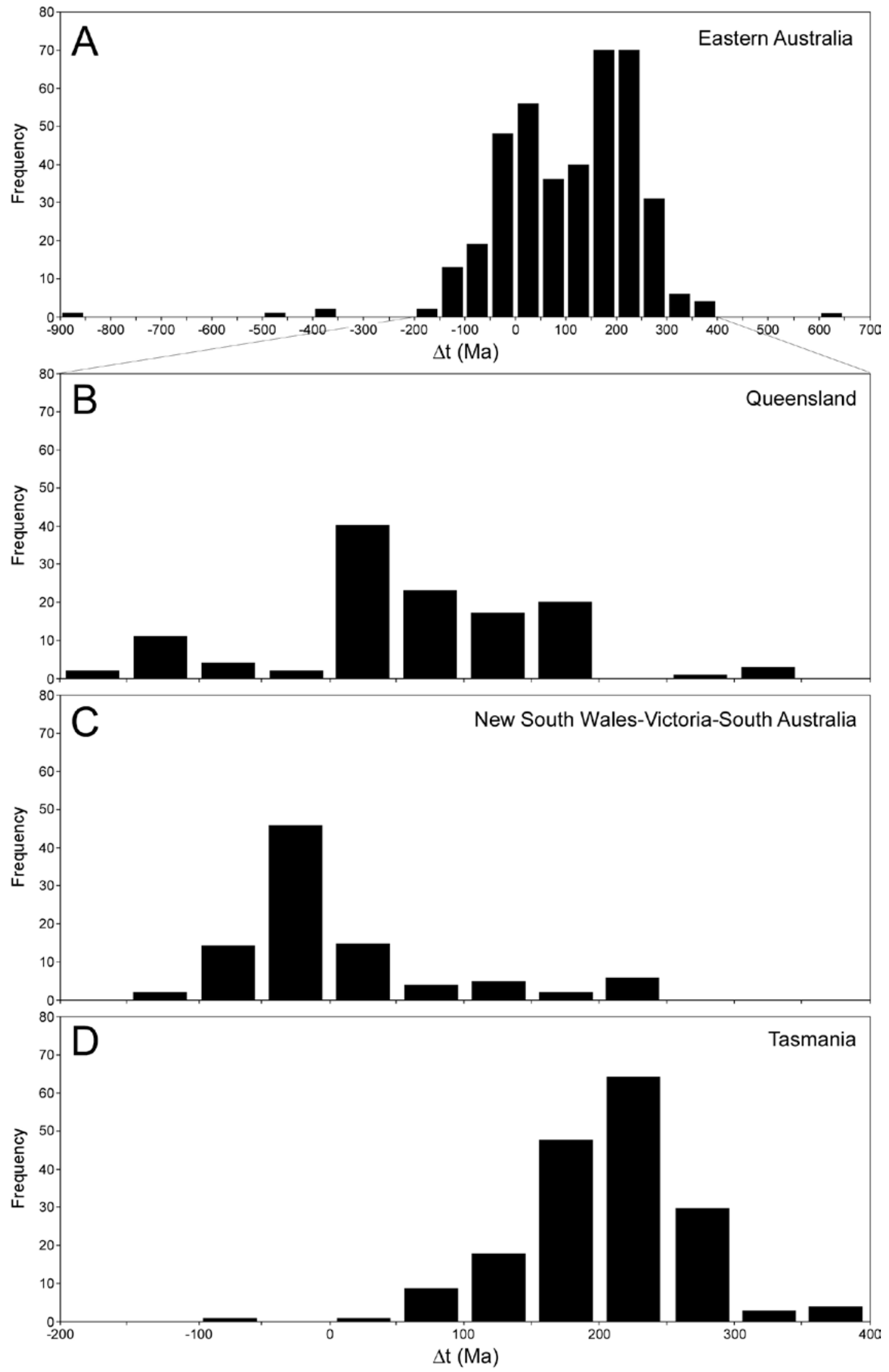

Figure 4.3 Histograms showing variations in $\Delta t$ in the Tasman Element for all of eastern Australia (A), Queensland (B), combined New South Wales, Victoria and South Australia (C), and Tasmania (D). Outliers have been excluded from parts $(B)$ to $(D)$, which are plotted over a smaller range in $\Delta t$. 


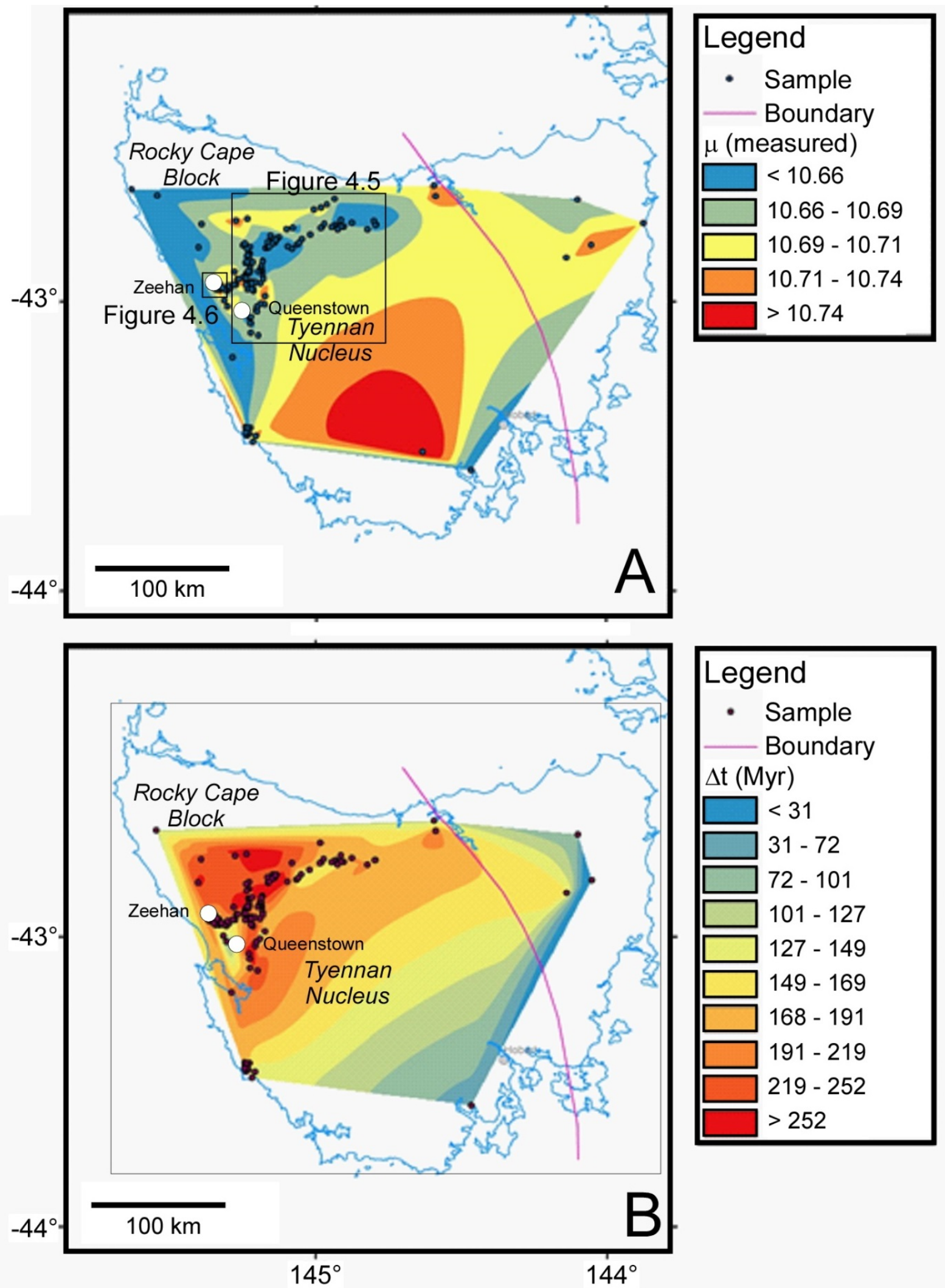

Figure 4.4 Maps of Tasmania showing $(A)$ variations in $\mu\left({ }^{238} \mathrm{U} /{ }^{204} \mathrm{~Pb}\right.$; calculated using the Cumming and Richards (1975) lead evolution model), and (B) variations in $\Delta t$. The colour stretches in parts $(A)$ and $(B)$ are different to those in Figures 4.1, 4.7 and 4.8.The locations of Figures 4.5 and 4.6 are shown on Figure 4.4A. 

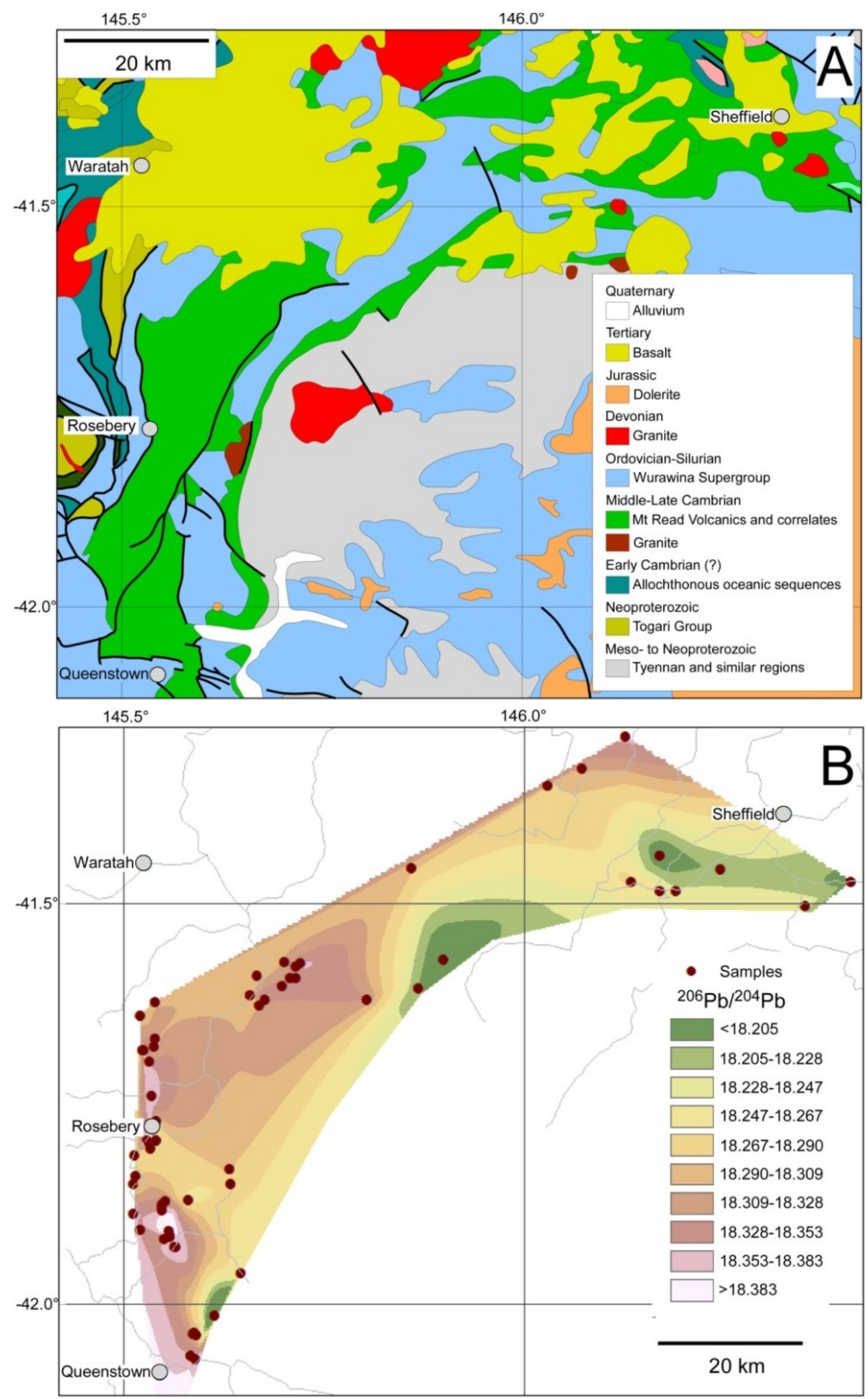

Figure 4.5 Maps showing (A) the geology of western Tasmania (modified after Seymour et al., 2007) and (B) variations in ${ }^{206} \mathrm{~Pb} /{ }^{204} \mathrm{~Pb}$ in Cambrian $(-500 \mathrm{Ma})$ volcanic-hosted massive sulphide and related deposits. The location of this figure is shown on Figure 4.4A. Image in part (B) constructed only using CSIRO data. 

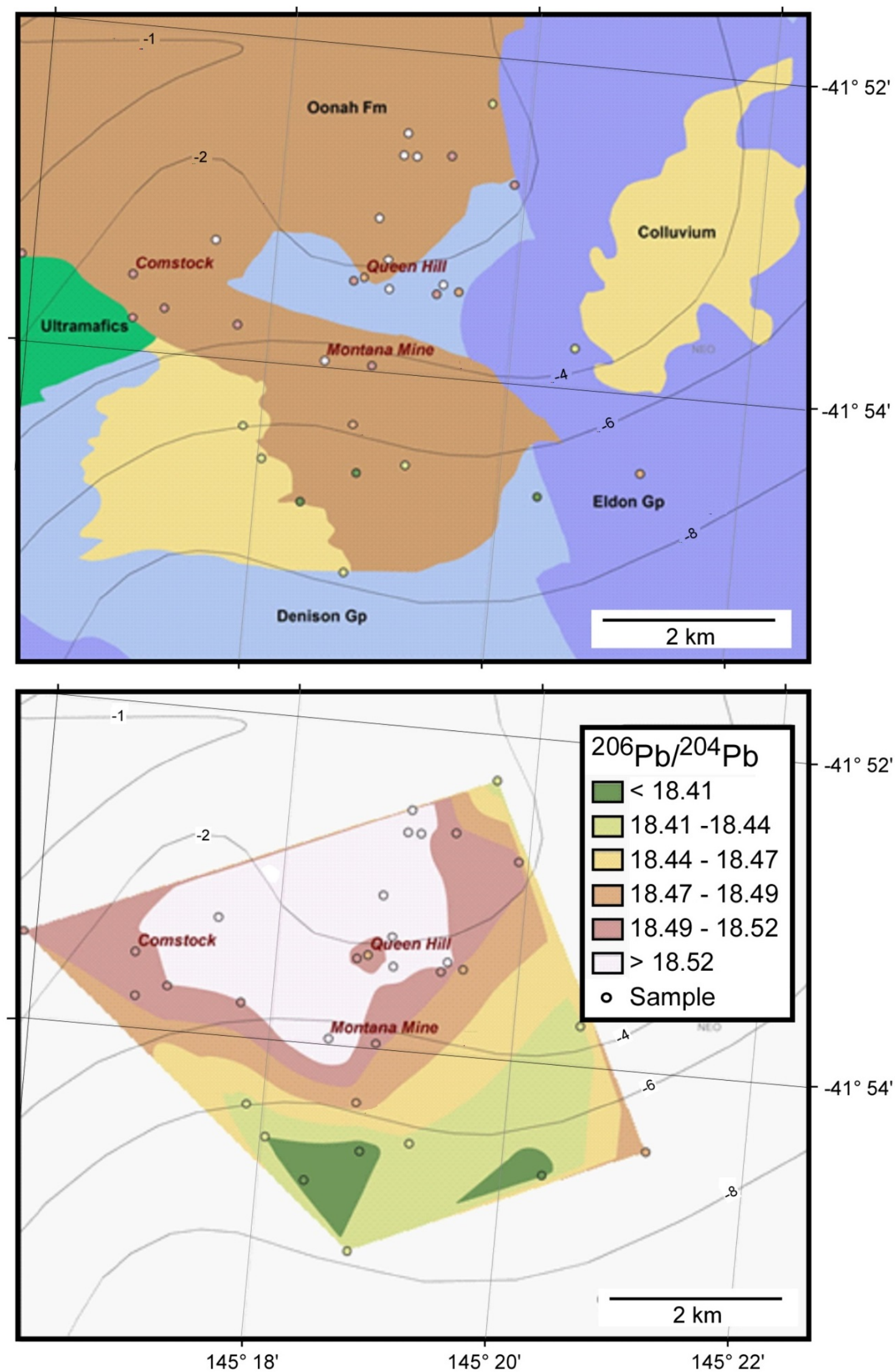

Figure 4.6 Maps showing (A) the geology of the Zeehan Pb-Ag-Zn-Sn district in western Tasmania, and (B) spatial variations in ${ }^{206} \mathrm{~Pb} /{ }^{204} \mathrm{~Pb}$ from analyses of mineralised samples. The contours indicate the inferred depth (in $\mathrm{km}$ ) to the Heemskirk Granite (Leaman and Richardson, 2003). The location of this figure is shown on Figure 4.4A. The image in part (B) was constructed only using CSIRO data. 

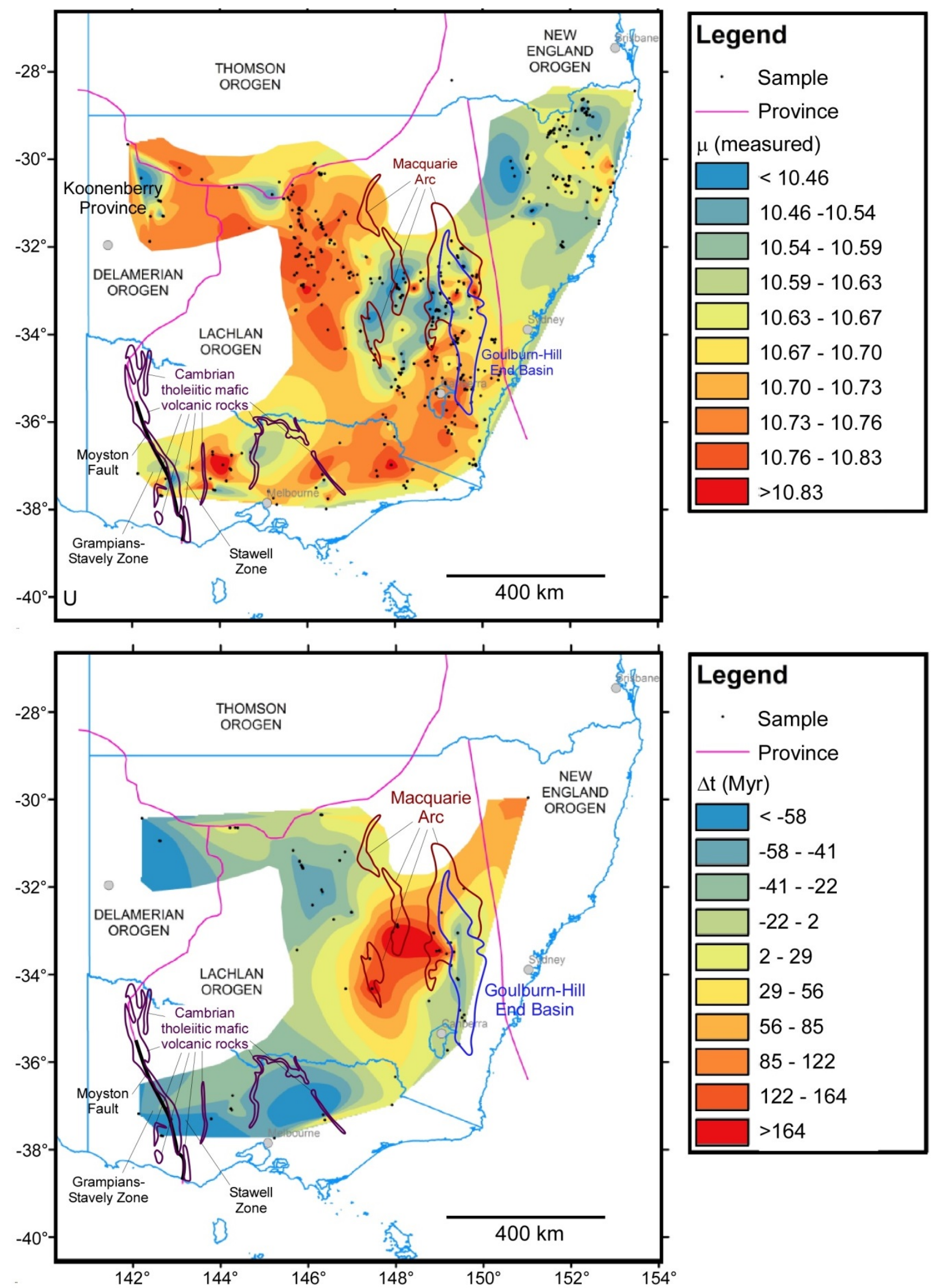

Figure 4.7 Variations in (A) $\mu\left({ }^{238} \mathrm{U}^{204} \mathrm{~Pb}\right.$; calculated using the Cumming and Richards (1975) lead evolution model) and (B) $\Delta t$ in New South Wales and Victoria. The distributions of the Macquarie Arc and the Goulburn-Hill End Basin are from Huston et al. (2016a). The distribution of Victorian Cambrian tholeiitic mafic volcanic rocks is from Vandenberg et al. (2000). 


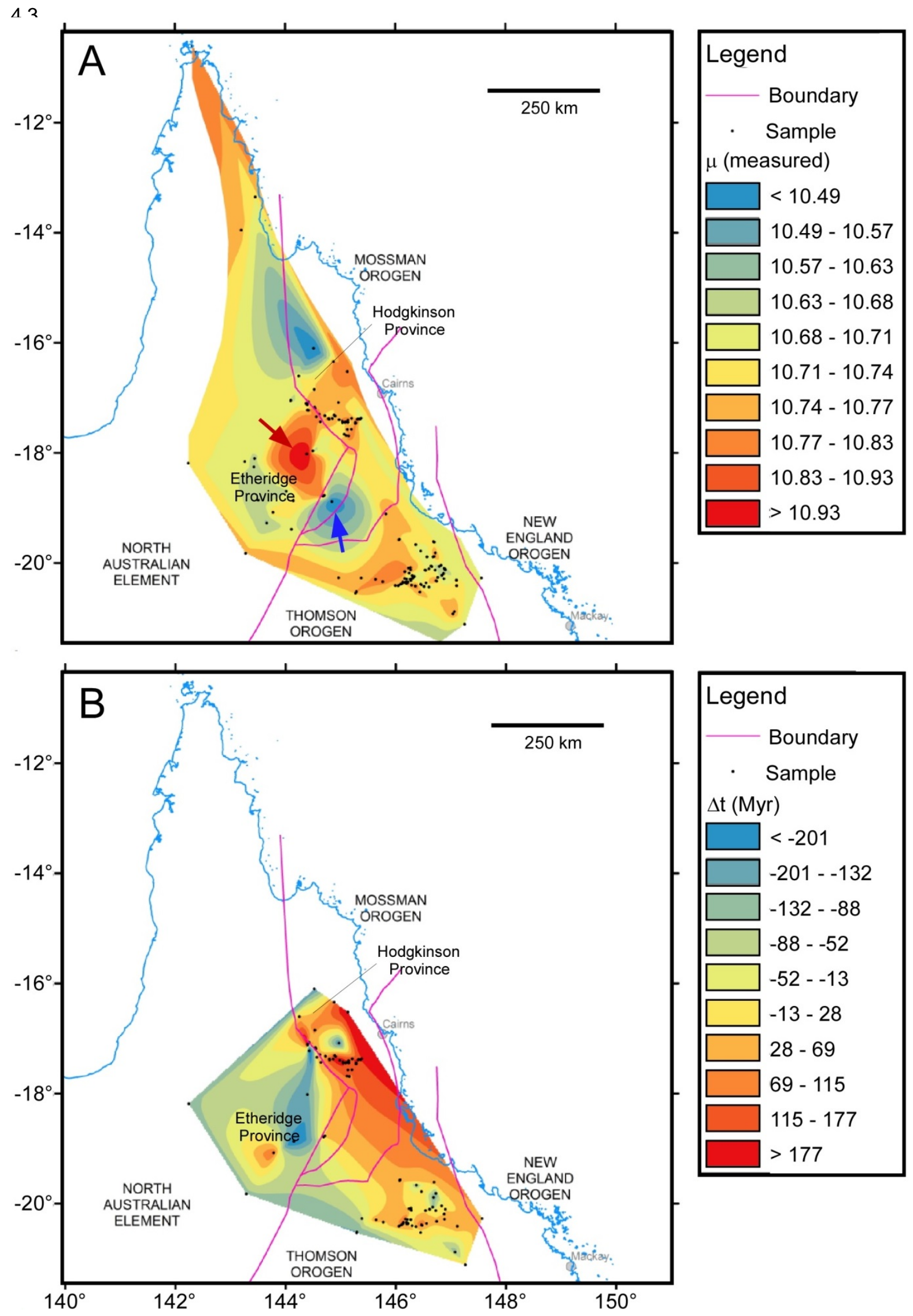

Figure 4.8 Variations in $(A) \mu\left(^{238} \mathrm{U}{ }^{204} \mathrm{~Pb}\right.$; calculated using the Cumming and Richards (1975) lead evolution model) and (B) $\Delta t$ in northern Queensland. The location is shown in inset to part (A). Coloured arrows indicate anomalies referred to in the text 


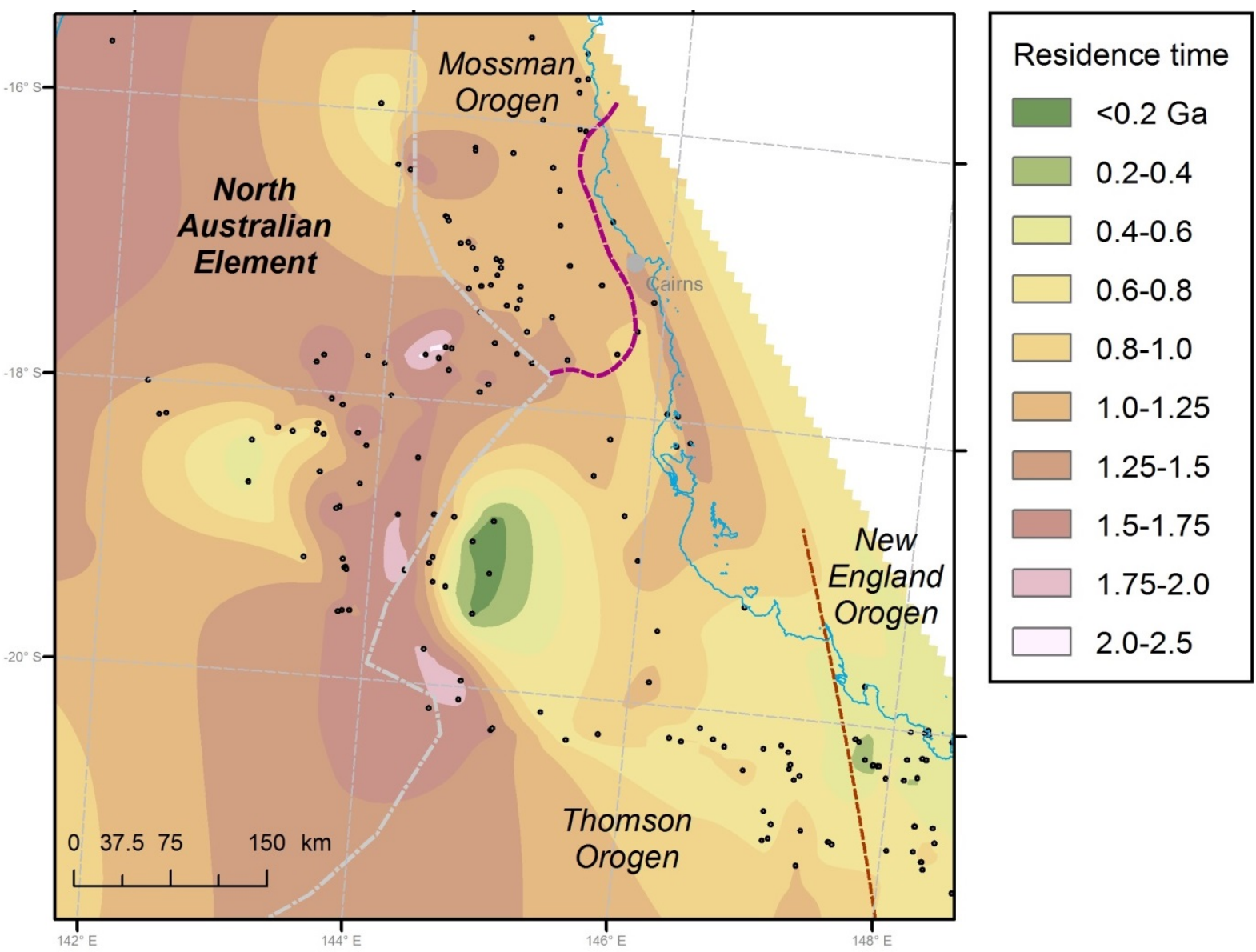

Figure 4.9 Interpolated $\mathrm{Nd}$ residence age $\left(T_{\text {Res }}\right)$ map for the northern part of the Tasman Element and surrounding North Australian elements. Sample locations are shown as dots. Champion (2013) present data sources and data.

Tasman Element, similar to conclusions made across the Tasman Line based on other isotopic systems (Webb and McDougall, 1968; Champion et al., 2010), and also geological interpretations of geological basement based on reflection seismic profile interpretations (Korsch et al., 2012). Similar isotopic zonation is also evident within the Carboniferous-Permian felsic magmatism to which much mineralisation in that region is directly related (Champion and Bultitude, 2013). 


\section{Discussion}

As presented in Section 4, the $\mu$ and $\Delta$ t parameters derived from lead isotope ratios from mineral deposits and occurrences in the Tasman Element show systematic patterns in space. These patterns highlight areas defined using other techniques including geological, metallogenic and $\mathrm{Nd}$ isotope mapping. Moreover, the zonation defined in particular by $\Delta t$ suggests that lead isotopes vary systematically relative to the Proterozoic Australian margin as defined by the Tasman line. This relationship further suggests that the observed lead isotope patterns may be related to crustal growth during subduction along the Australian-Antarctic convergent margin in the Paleozoic.

\subsection{Paleozoic tectonic evolution of eastern Australia}

Although there is disagreement on many of the details, there is a general consensus that the growth of the eastern Australian seaboard has involved generally west-dipping subducton with periodic accretion of exotic elements (arcs, crustal blocks and crustal ribbons) beginning during the Cambrian (or before) and continuing until at least the Mesozoic (see Champion et al., 2009, Champion, 2016 and references therein for a summary). In general, this process involved the subduction of a proto-Pacific oceanic plate underneath an over-riding continental plate made of elements that amalgamated during the Proterozoic (proto-Australia). In the discussion below we present a model in which we infer that the variations in lead isotopes in the Tasman Element can be accounted for by the interaction between the proto-Australia and proto-Pacific plates during subduction.

\subsection{The proto-Australia and proto-Pacific isotopic systems}

Münker (2000) initially suggested the presence of two broad isotopic sources along the Australia-New Zealand segment of the Phanerozoic Australian-Antarctic convergent margin. The data and patterns presented above are consistent with such a model, with a lead system characterised by two endmembers: one with negative to slightly positive $\Delta$ t values which we term the proto-Australia system, and a second system having very positive $\Delta \mathrm{t}$ (>150 Myr) termed the proto-Pacific system.

To model the evolution of these two proposed systems we have used the Lachlan crustal and Lachlan mantle curves of Carr et al. (1995; Figure 5.1). Evolution of the proto-Australia system was modelled by varying $\mu$ (between 13.0 and 13.3) associated with the Carr et al. (1995) Lachlan crustal curve to produce a series of curves shown in red in Figure 5.1. The most juvenile (lowest $\mu(=13.0)$ ) curve was constrained to pass through the Ponto (Koonenberry Province) and Mount Ararat (Stawell Zone) prospects (locations not shown). Using these curves model ages of 550-570 Ma were calculated for deposits inferred to have ages of $\sim 520 \mathrm{Ma}$ (Ponto, Mount Ararat and Kanmantoo). This proto-Australia isotopic system model gives similar model ages to the Cumming and Richards (1975) model, although the absolute calculated $\mu$ values differ due to differences in the way the models were constructed.

Evolution of the proto-Pacific isotopic system was modelled by varying $\mu$ (between 10.2 and 10.0) associated with the Carr et al. (1995) Lachlan mantle evolution curve so that the most evolved (highest $\mu(=10.2)$ ) curve passed through deposits in the Mount Read Volcanics of western Tasmania (another region characterised by large negative $\Delta t$ signatures). Model ages from this isotopic system, which is relevant to western Tasmania, the Macquarie Arc and much of the New England Orogen, were generally within $30 \mathrm{Myr}$ of the true age of formation of mineral deposit (where known). 
Hence, as discussed by Huston et al. (2016a), lead isotope evolution in eastern Australia can be modelled as the interaction between two end-member lead isotopic systems, with intermediate characteristics caused by mixing of the two systems. This is consistent with Münker (2000) who found that lead isotope variations in the Takaka Terrane of New Zealand indicate interaction between a highly radiogenic reservoir (which produced the Devil River Volcanics - equivalent to our proto-Pacific system) dominated by subducted sediments with a dominant Archean provenance, and a less radiogenic reservoir more characteristic of Proterozoic terranes (our proto-Australia system). The tectonic and metallogenic significance of this interaction is discussed below.

\subsection{Metallogenic and tectonic significance}

Although there is disagreement on details, there is a broad consensus that the Tasman Element is the product of Paleozoic to Mesozoic convergence between a proto-Pacific plate and a previously assembled Proterozoic Australian landmass comprising the West, North, South and Central Australian elements (Münker and Crawford, 2000; Gray and Foster 2004; Champion, 2016, and references therein). Although there may have been complications, for example, collision of oceanic arc fragments often interpreted to involve reversal of subduction polarity (e.g., Crawford and Berry, 1992; Aitchison and Flood, 1992; Aitchison and Buckman, 2012; Offler and Murray, 2011; Gibson et al., 2015), and multiple subduction zones (e.g., Soesoo et al., 1997; Gray and Foster, 2004), this tectonic system was likely dominated by west-dipping subduction, with Proterozoic Australia as the over-riding plate (Cawood, 2005; Glen, 2013). In this tectonic setting, the Pacific lead isotopic system reflects the subducting proto-Pacific plate and interpreted accreted oceanic arc terranes, and the proto-Australia isotopic system reflects the Proterozoic Australian plate (the northern Lachlan Orogen best fits the Proterozoic Australian lead model).

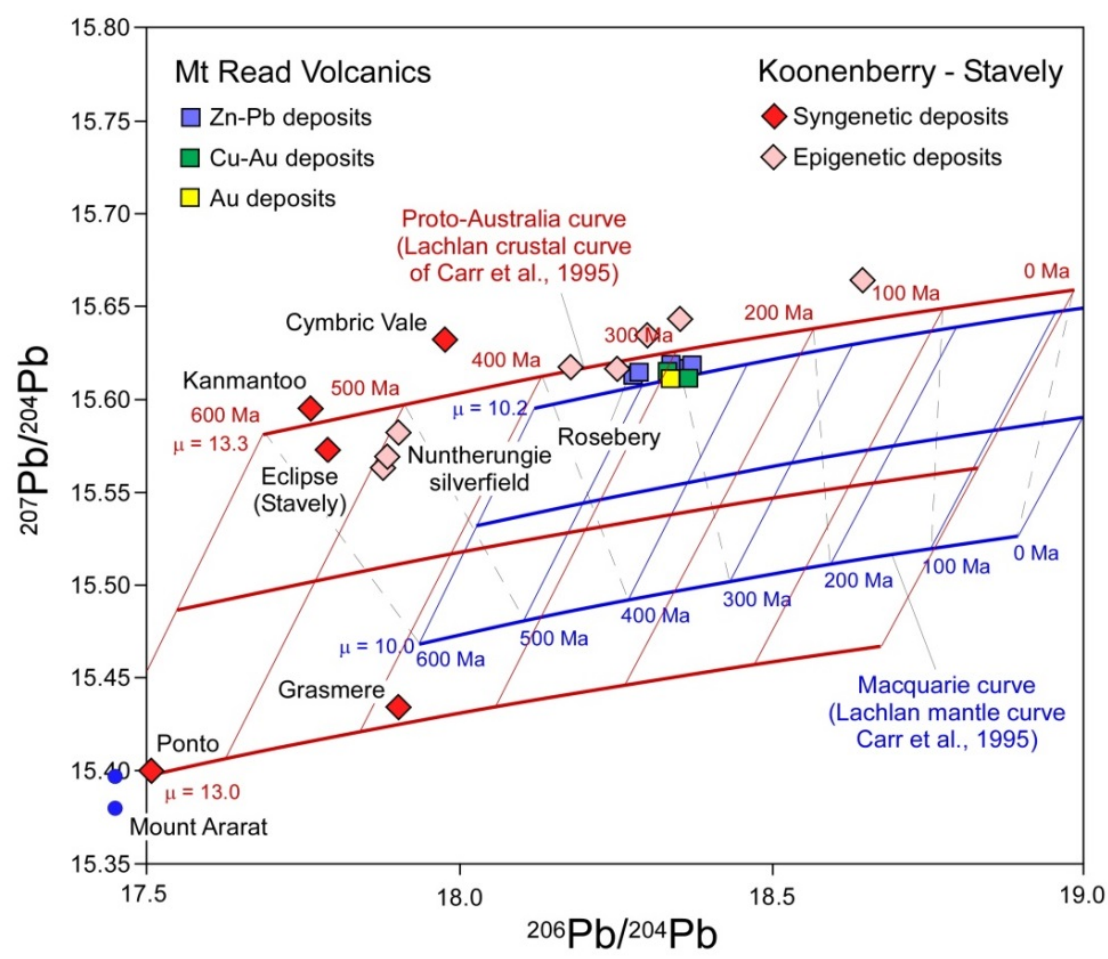

Figure 5.1 Comparison of high precision lead isotope from selected Cambrian and early Ordovician deposits from the Tasman Element with two lead evolution systems. The first (red) is termed the proto-Australia system, and the second (blue) is termed the proto-Pacific system. Methods whereby these systems were derived are described in the text. 
In this context, variations in $\mu$ and $\Delta$ t provide some constraints on tectonics and metallogenesis based upon our model. Zones of low $\mu$, for example, suggest involvement of a relatively juvenile lead source, but this source can have two origins, either from the subducting proto-Pacific plate and/or mantle wedge or from lithospheric mantle that forms part of the over-riding plate. Consideration of the $\Delta t$ map can constrain this origin. The zone of low $\mu$ associated with the Macquarie Arc is also characterised by $\Delta t$ values commonly in excess of $150 \mathrm{Myr}$, suggesting that the melts that produced these rocks were derived either directly from the subducting proto-Pacific plate or from mantle strongly metasomatised by volatiles (including lead) extracted from this plate. This interpretation is compatible with that of Forster et al. (2011), who found that deposits in the Macquarie Arc derived lead from a mantle-like lead isotope reservoir (i.e. subducted proto-Pacific oceanic crust) without significant contributions of crustal lead (i.e. proto-Australia crust). Forster et al. $(2011,2015)$ reported that some mineralised zones in the Macquarie Arc region zones such as Peak Hill (high sulfidation epithermal deposit) and Decoy, which, while not porphyry deposits, have an unradiogenic lead isotope signature similar to Cambrian VAMS systems such as Ponto. Such signatures may reflect Pb scavenged from the crust upon which the Macquarie Arc was built.

Similarly, high $\Delta t$ values in parts of the New England Orogen, particularly the eastern, outboard parts, and, possibly, in the Hodgkinson Province suggest a significant proto-Pacific influence on the metallogenesis of these provinces.

In contrast, local zones of juvenile crust elsewhere in the Tasman Element, for example in the Koonenberry Province, the Stawell Zone or northern Queensland, are characterised by lead likely to be from Proterozoic Australia, as indicated by low $\Delta$ t. Lead in these zones was derived, at least in part, from lithospheric mantle underlying proto-Australia, possibly introduced during formation of arc or back-arc basins.

Empirically, regions characterised by juvenile lead from the proto-Pacific plate appear to be better mineralised, particularly for copper and gold, than regions characterised by juvenile Australian lead. The Macquarie porphyry copper-gold province in New South Wales is closely associated with juvenile lead (Carr et al., 1995; Forster et al., 2015) with a proto-Pacific signature. This association is consistent with genetic relationships between magmatism and these deposits (see discussion in Champion and Huston, 2016).

A proto-Pacific signature also characterises the strongly-mineralised Mount Read Volcanics in western Tasmania, but, in this case, the the high $\mu$ character of the signature implies a more evolved, crustal source. This signature is unique in the Tasman Element and makes direct correlation with the Mount Stavely Volcanic Complex (e.g. Crawford et al., 2003) and Koonenberry Province problematic, even though all three provinces have similar ages ( $-500 \mathrm{Ma})$ and possibly similar interpreted settings (Crawford et al., 2003). Based on the lead isotope data, an alternative interpretation is that the lead signature of these provinces reflects either provinciality of the lead signature along the arc-subduction system (e.g., variation produced by changing provenance of sediments being subducted as suggested by Münker (2000)) and/or that the tectonic setting and location of western Tasmania is different. The lead isotope data could be interpreted to suggest that western Tasmania was part of the proto-Pacific and not the Proterozoic Australian plate. This interpretation is more consistent with tectonic models (e.g. Gibson et al., 2011; Cayley, 2012) that suggest that the West Tasmania Terrane was significantly further south relative to its persent-day position.

As suggested by Münker (2000), the Pacific lead system requires a significant component of long-lived radiogenic growth. Figure 5.2, which is modified after an original diagram in Münker (2000), compares initial ratios of deposits inferred to be associated with Pacific lead in this study with potential original source regions (at $500 \mathrm{Ma}$ ). As pointed out by Münker (2000), the evolution of the Pacific isotope system requires a component with long-term evolution from an originally highly radiogenic source, 
most likely derived from an Archean province. Of the possible Archean provinces considered by Münker (2000), the closest match is the Abitibi Subprovince in the Superior Province of Canada; ${ }^{207} \mathrm{~Pb} /{ }^{204} \mathrm{~Pb}$ ratios (at $500 \mathrm{Ma}$ ) of other potential sources (Enderby Land, Wyoming Province, and Slave Province) are much higher than those from western Tasmania and the Macquarie Arc (Figure 5.2), although the Pacific lead data could be matched using mixtures between MORB and these other Archean terranes (e.g., Münker, 2000). In contrast, proto-Australia, as represented by Ponto and Mount Ararat in Figure 5.2, does not require a highly radiogenic source.

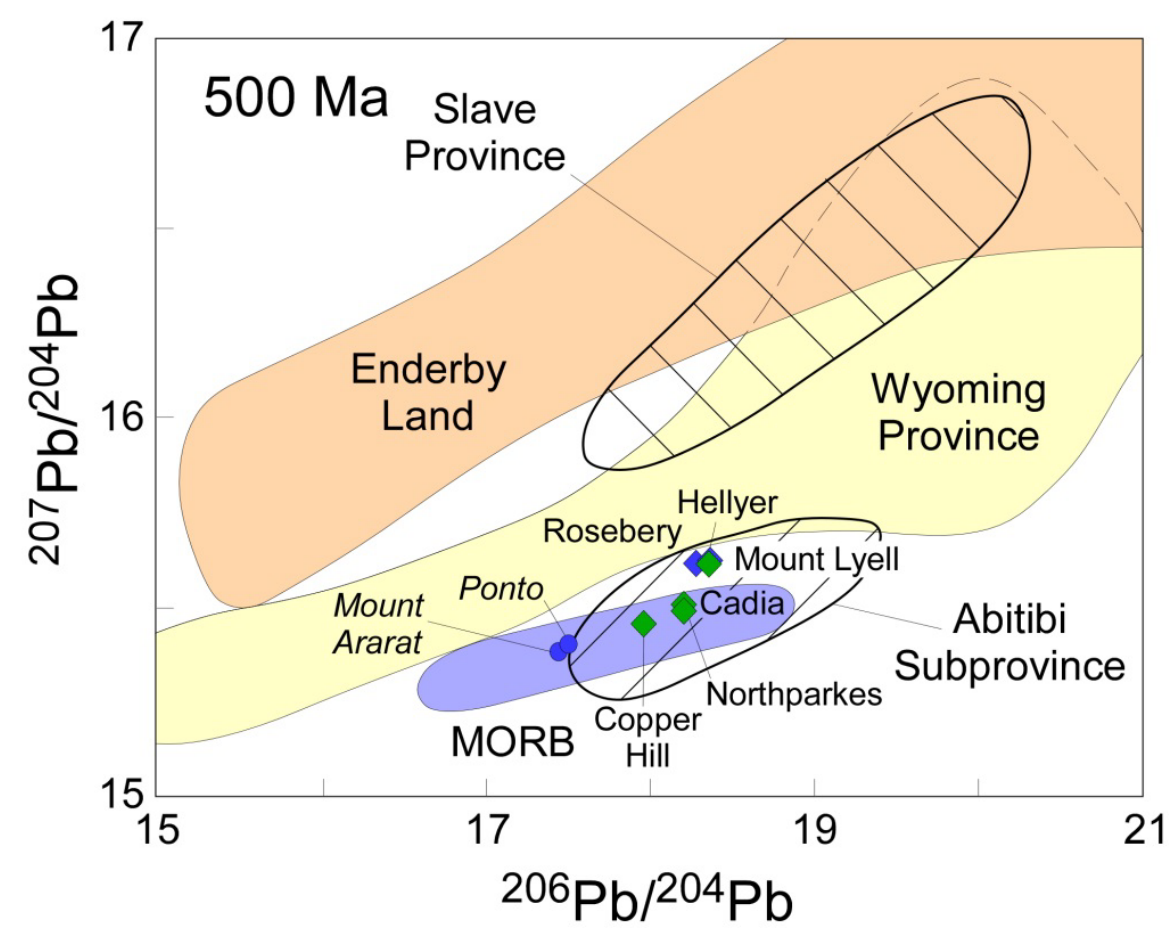

Figure $5.2{ }^{206} \mathrm{~Pb} /{ }^{204} \mathrm{~Pb}$ versus ${ }^{207} \mathrm{~Pb} /{ }^{204} \mathrm{~Pb}$ diagram showing initial least radiogenic isotope composition of deposits in western Tasmania and the Macquarie Arc overlain on possible source provinces of the Pacific lead isotopic system (calculated at $500 \mathrm{Ma}$ ). The compositons of the Ponto and Mount Ararat deposits, which have a juvenile proto-Australia signature are also shown for comparison. Modified after Münker (2000).

As pointed out by Huston et al. (2016a) for southeastern Australia, certain types of mineral deposits are associated with crust that has specific lead isotope characteristics. For example, granite-related tin and molybdenite deposits (e.g. Ardlethan and Unicorn) in the Lachlan Orogen are concentrated in the high- $\mu$ Central Zone, and porphyry and related copper-gold deposits in the Macquarie Arc are associated with low- $\mu$ portions of the Eastern Zone (Figure 4.1). It is interesting to note that several volcanic-hosted massive sulphide and other deposits adjacent to the low- $\mu$ Macquarie Arc are also enriched in gold (e.g. Decoy (Forster et al., 2015) and McPillamys). However, this association of copper-gold deposits with low- $\mu$ zones is not universal, as the Mt Lyell copper-gold district in western Tasmania is characterised by intermediate- $\mu$ lead, as are copper-gold deposits in the central Cobar district in north-central New South Wales. However, part of this difference may relate to genetic associations for these respective $\mathrm{Cu}$-Au deposits. As discussed by Champion and Huston (2016) for the Sm-Nd system, magmatic porphyry Cu-Au deposits in eastern Australia, such as within the Macquarie Arc, are related to isotopically juvenile magmatism or are located within crustal zones dominated by such magmatism. 


\section{Conclusions}

Collation of older, low-precision data (mostly from CSIRO) and collection of new, high-precision data have allowed the production of an extensive spatially-located dataset encompassing lead isotope ratios from mineral deposits in the Tasman Element of eastern Australia. Least radiogenic isotope ratios from individual deposits have been used to calculate derived parameters, including model age, $\mu$, and the difference between true and model ages $(\Delta t)$. Spatial contouring of $\mu$ and $\Delta t$, which are both largely independent of deposit age and deposit type, has identified systematic patterns that have implications not only to metallogenesis, but also to the Phanerozoic tectonic evolution of Eastern Australia.

Variations in $\mu$ define boundaries at the orogen, province and zone scales. The boundary between the Lachlan and New England orogens is accompanied by a decrease in $\mu$, and within the Lachlan Orogen, the Central Province is characterised by $\mu$ that is significantly higher than in the adjacent Eastern and Western provinces. Within the Eastern Province the Cu-Au-rich Macquarie Arc is characterised by significantly lower $\mu$ relative to adjacent rocks. The changes in $\mu$ are interpreted to reflect boundaries between more evolved crust (higher $\mu$ ) and more juvenile crust (lower $\mu$ ).

Although variations in $\Delta t$ in some ways mirror variations in $\mu$, in general the patterns are significantly different. Not only is the Macquarie Arc characterised by anomalously low $\mu$, but it is charaterised by very high $\Delta \mathrm{t}$ (generally above $200 \mathrm{Myr}$ ). Other regions characterised by very high $\Delta \mathrm{t}$ include western Tasmania, the southeastern New England Orogen, and the Hodgkinson Province. These anomalies are within a broad pattern of decreasing $\Delta t$ from east to west, with Paleozoic deposits within or adjacent to Proterozoic crust characterised by $\Delta t$ values of 0 Myr or below.

The patterns in $\Delta t$ are interpreted to reflect the presence of the two major tectonic components involved in the Paleozoic Tasman margin in Australia (cf., Münker, 2000): subducting proto-Pacific crust $(\Delta t>150 \mathrm{Myr})$, and Proterozoic Australia crust $(\Delta \mathrm{t}<50 \mathrm{Myr}$ ) on the over-riding plate. Proterozoic Australia crustal sources are interpreted to dominate the western parts of the Tasman Element and Proterozoic crust further to the west, whereas Pacific crustal sources are inferred to characterise western Tasmania and much of the eastern part of the Tasman Element.

The lead isotope data, as reflected by $\Delta t$, suggest that Cambrian rocks in the Mount Read Volcanics of western Tasmania formed in the proto-Pacific plate (e.g., Münker and Crawford, 2000), whereas similar-aged rocks in the Grampians-Stavely Zone and the Koonenberry Province formed in the overriding Proterozoic Australian plate, making direct tectonic correlation between Cambrian rocks in western Tasmania and western Victoria and New South Wales problematic. 


\section{Acknowledgements}

The final version of this record benefited from thorough reviews by Natalie Kositcin and Anthony Schofield. The efforts of staff at CSIRO, both past and present, are acknowledged for their decadeslong effort to produce a lead isotope database covering Australia that has allowed the present contribution. This paper is published with the permission of the CEO, Geoscience Australia 


\section{References}

Aitchison, J. C., Buckman, S. 2012. Accordion vs. quantum tectonics: Insights into continental growth processes from the Paleozoic of eastern Gondwana. Gondwana Research 22, 674-680.

Aitchison, J. C., Flood, P.G. 1992. Early Permian transform margin development of the southern New England orogen, eastern Australia (eastern Gondwana). Tectonics 11, 1385-1391.

Bennett, V. C., DePaolo, D. J., 1987. Proterozoic crustal history of the western United States as determined by neodymium isotopic mapping. Geological Society of America Bulletin 99, 674-685.

Birch, W. D., Vandenberg, A. H. M. 2003. Introduction - Continuing the advance of Victoria geology. In: Birch, W. D. (ed) Geology of Victoria, pp. 1-13. Geological Society of Australia Special Publication 23. Geological Society of Australia (Victoria Division).

Black, L. P., Richards, J.R. 1972. Isotopic composition and possible genesis of ore leads in northeastern Queensland, Australia. Economic Geology 67, 1168-1179.

Carr, G. R., Dean, J. A., Suppel, D. W, Heithersay, P. S. 1995. Precise lead isotope fingerprinting of hydrothermal activity associated with Ordovician to Carboniferous metallogenic events in the Lachlan fold belt of New South Wales. Economic Geology 90, 1467-1505.

Cawood, P. A. 2005. Terra Australis Orogen: Rodinia breakup and development of the Pacific and lapetus margins of Gondwana during the Neoproterozoic and Palaeozoic. Earth Science Reviews 69, 249-279.

Cayley, R. A. 2012. Oroclinal folding in the Lachlan Fold Belt: consequence of southeastdirected Siluro-Devonian subduction rollback superimposed on an accreted Ordovician arc assemblage in eastern Australia. Geological Society of Australia Extended Abstracts 103, 34-43.

Champion, D. C., 2013. Neodymium depleted mantle model age map of Australia: explanatory notes and user guide. Geoscience Australia Record 2013/044. http://dx.doi.org/10.11636.

Champion, D. C., Bultitude, R. J. 2013. The geochemical and Sr-Nd isotopic characteristics of Paleozoic fractionated S-types granites of north Queensland: Implications for S-type granite petrogenesis. Lithos 162-163, 37-56.

Champion, D. C., Cassidy, K. C. 2008.Using geochemistry and isotopic signatures of granites to aid mineral systems studies: an example from the Yilgarn Craton. Geoscience Australia Record 2008/09, 7-16.

Champion, D. C., Huston, D. L. 2016. Radiogenic isotopic, ore deposits and metallogenic terranes: novel approaches based on regional isotopic maps and the mineral system concept. Ore Geology Reviews 76, 229-256.

Champion, D. C., Kositcin, N., Huston, D. L., Mathews, E., Brown, C., 2009. Geodynamic Synthesis of the Phanerozoic of eastern Australia and Implications for metallogeny. Geoscience Australia Record 2009/18.

Champion, D. C., Bultitude, R. J., Blevin, P. L. 2010. Geochemistry and isotope systematics of Carboniferous to Triassic felsic magmatism in northeastern Australia-putting the New England Orogen in its place. In Buckman, S., Blevin, P. L. (eds.) New England Orogen 2010. Proceedings of a conference held at the University of New England, Armidale, New South Wales, Australia, November 2010. University of New England, Armidale, pp. 112-18.

Champion, D. C. 2016. Geodynamic Synthesis of the Phanerozoic of eastern Australia. Second Edition. Geoscience Australia Record 2016/07.

Crawford, A. J., Berry, R. F., 1992. Tectonic implications of Late Proterozoic - Early Palaeozoic igneous rock associations in western Tasmania. Tectonophysics 214, 37-56. 
Crawford, A. J., Cayley, R. A., Taylor, D. H., Morand, V. J., Gray, C. M., Kemp, A. I. S., Wohlt, K. E., VandenBerg, A. H. M., Moore, D. H., Maher, S., Direen, N. G., Edwards, J., Donaghy, A. G., Anderson, J. A., Black, L. P. 2003. Neoproterozoic and Cambrian continental rifting, continent-arc collision and post-collisional magmatism. In: Birch, W. D. (ed) Geology of Victoria, pp. 73-94. Geological Society of Australia Special Publication 23. Geological Society of Australia (Victoria Division).

Cumming, G. L., Richards, J. R. 1975. Ore lead isotope ratios in a continuously changing Earth. Earth and Planetary Science Letters 28, 155-171.

Dickin, A. P. 1995. Radiogenic isotope geology. Cambridge University Press, 490 p.

Forster, D. B., Carr, G. R., Downes, P. M. 2011. Lead isotope systematics of ore systems of the Macquarie Arc - Implications for arc substrate. Gondwana Research 19, 686-705.

Forster, D. B., McInnes, P., Downes, P. M., Maas, R., Norman, M., Blevin, P. L. 2015. New lead isotopic and geochronologic constraints on mineralisation in the Macquarie Arc - insights from the Lake Cowal district, New South Wales. Quarterly Notes of the Geological Survey of New South Wales 144.

Gibson, G. M., Morse, M. P., Ireland, T. R., Nayak, G. K. 2011. Arc-continent collision and orogenesis in western Tasmanides: Insights from reactivated basement structures and formation of an oceancontinent transform boundary off western Tasmania. Gondwana Research 19, 608-627.

Gibson, G. M., Champion, D. C., Ireland, T. R., 2015. Preservation of a fragmented late Neoproterozoic-earliest Cambrian hyper-extended continental-margin sequence in the Australian Delamerian Orogen. Geological Society, London, Special Publications, 413. http://dx.doi.org/10.1144/SP413.8

Glen, R. A. 2013. Refining accretionary orogen models for the Tasmanides of eastern Australia. Australian Journal of Earth Sciences 60, 315-370.

Gray, D. R., Foster, D. A. 2004. Tectonic review of the Lachlan Orogen, southeast Australia: historical review, data synthesis and modern perspectives. Australian Journal of Earth Sciences 51, 773817.

Greenfield, J. E., Gilmore, P. J., Mills, K. J., compilers. 2010. Explanatory notes for the Koonenberry Belt geological maps. Geological Survey of New South Wales Bulletin 35.

Greenfield, J. E., Musgrave, R. G., Bruce, M. C., Gilmore, P. J., Mills, K.J. 2011. The Mount Wright Arc: a Cambrian subduction system developed on the continental margin of East Gondwana, Koonenberry Belt, eastern Australia. Gondwana Research 19, 650-669.

Henderson, R. A., Donchak, P. J. T., Withnall, I. W., with contributions from Adams, C. J., Bultitude, R. J., Champion, D. C., Davis, B. K., Hutton, L. J. and Wormald, R. 2013. Chapter 3. Mossman Orogen. In P. A. Jell (ed.) Geology of Queensland. Geological Survey of Queensland, pp. 225-304.

Huston, D. L., Champion, D. C., Cassidy, K. F. 2014. Tectonic controls on the endowment of Neoarchean cratons in volcanic-hosted massive sulfide deposits: evidence from lead and neodymium isotopes. Economic Geology 109, 11-26.

Huston, D. L., Champion, D. C., Mernagh, T. P., Downes, P. M., Jones, P., Carr, G., Forster, D., David, V. 2016a. Metallogenesis and geodynamics of the Lachlan Orogen: New (and old) insights from spatial and temporal variations in lead isotopes. Ore Geology Reviews 76, 257-267.

Huston, D. L.,Mernagh, T. P., Hagemann, S. G., Doublier, M. P., Fiorentini, M., Champion, D. C., Jaques, A. L., Czarnota, K., Cayley, R., Skirrow, R., Bastrakov, E. 2016. Tectonometallogenic systems - the place of mineral systems within tectonic evolution. Ore Geology Reviews 76, 168210

Kistler, R. W., Peterman, Z.E. 1973. Variations in Sr, Rb, K, Na, and initial $\mathrm{Sr}^{87} / \mathrm{Sr}^{86}$ in Mesozoic granitic rocks and intruded wall rocks in central California. Geological Society of America Bulletin 84, 3489-3512.

Korsch, R. J., Huston, D. L., Henderson, R. A., Blewett, R. S., Withnall, I. W., Fergusson, C. L., Collins, W. J., Saygin, E., Kositcin, N., Meixner, A. J., Chopping, R., Henson, P. A., Champion, D. C., Hutton, L. J., Wormald, R., Holzschuh, J., Costelloe, R. D. 2012. Crustal architecture and geodynamics of north Queensland, Australia: insights from deep seismic reflection profiling. Tectonophysics 572, 76-99. 
Leaman, D. E., Richardson, R. G. 2003. A geophysical model of the major Tasmanian granitoids. Tasmanian Geological Survey Record 11.

Münker, C. 2000. The isotope and trace element budget of the Cambrian Devil River arc system, New Zealand: identification of four source components. Journal of Petrology 41, 759-788.

Münker, C., Crawford, A. J. 2000. Cambrian arc evolution along the SE Gondwana active margin: A synthesis from Tasmania-New Zealand-Australia-Antarctica correlations. Tectonics 19, 415-432.

Offler, R., Murray, C. G. 2011. Devonian volcanics in the New England Orogen: tectonic setting and polarity. Gondwana Research 19, 706-15.

Seymour, D. B., Green, G. R., Calver, C. R.. 2007. The geology and mineral deposits of Tasmania : a summary. Tasmanian Geological Survey Bulletin 72.

Slocum, T. A., McMaster, R. B., Kessler, F. C., Howard, H. H., 2009. Thematic Cartography and Geovisualization. Third Edition. Pearson Prentice Hall, New Jersey, 561 p.

Soesoo, A., Bons, P. D., Gray, D. R., Foster, D. A. 1997. Divergent double subduction; tectonic and petrologic consequences. Geology 25, 755-758.

Stacey, J. S.; Kramers, J. D. 1975. Approximation of terrestrial lead isotope evolution by a two-stage model. Earth and Planetary Science Letters 26, 207-221.

Ulrich, T., Golding, S. D., Kamber, B. S., Zaw, K., Taube, A. 2003. Different mineralization styles in a volcanic-hosted ore deposit: the fluid and isotopic signatures of the Mt Morgan Au-Cu deposit, Australia. Ore Geology Reviews 22, 61-90.

Vandenberg, A. H. M., Willman, C. E., Maher, S., Simons, B. A., Cayley, R. A., Taylor, D. H., Morand, V. J., Moore, D. H., Radkovic, A. 2000.The Tasman fold belt system in Victoria. Geological Survey of Victoria Special Publication, $462 \mathrm{p}$.

Webb, A. W., McDougall, I. 1968. The geochronology of the igneous rocks of eastern Queensland. Journal of the Geological Society of Australia 15, 313-346.

Wooden, J. L., DeWitt, E. 1991. Pb isotopic evidence for a major early crustal boundary in western Arizona. Arizona Geological Society Digest 19, 27-50. 


\section{Appendix A Lead isotope data from the Tasman Element of eastern Australia}

Appendix $A$ is an Excel workbook containing a compilation of lead isotope analyses of samples collected from mineral occurrences and deposits from the Phanerozoic Tasman Element and from Phanerozoic deposits in adjacent Proterozoic provinces. It can be accessed at http://www.ga.gov.au/metadata-gateway/metadata/record/110383. During compilation, multiple analyses of each sample/mineral pair were averaged, and poor-quality analyses (defined as having a CSIRO Q-factor (indication of analytical quality) of 7-9 (from a total scale of 0-9)) were excluded, except when better quality analyses were not available. In some cases where multiple analyses of a sample/mineral were available, outliers were also excluded. Metadata for this dataset are presented in Appendix B. 


\section{Appendix B Description of data included in lead isotope data from the Tasman Element of eastern Australia}

This appendix briefly describes data included in Appendix A. Table B1 describes the data types included in Appendix A. Column headings are suitable for incorporation into GIS data processing packages. Appendix A is an Excel workbook with two tabs, the first containing the data, and the second the references.

\section{B.1 Location data}

The first five columns (A-E) of Appendix A contain information regarding the location of the sample. The first and second column (A-B) indicate the name of the deposit and lens (if appropriate) from whence the sample was obtained. The third column (C) indicates the state, and the fourth and fifth columns (E-F) indicate the longitute and latitude of the sample. For samples in which exact location data are not available (aside from the name), location data for the occurrence/prospect were extracted from MINLOC and assigned to the sample. Location data are reported to four decimal degreee places, which corresponds to a nominal accuracy of $\sim 100 \mathrm{~m}$. However, in many cases, the true accuracy of the location is not that well known. In all cases the locations are reported relative to the GDA94 datum.

\section{B.2 Sample name and description}

For each sample, a Geoscience Australia sample ID number was assigned (column F). In addition to this number, other sample ID numbers (e.g., University, CSIRO or State survey sample numbers) are in column G. For some samples, additional, more detailed location data (e.g., drill hole number and depth; location of sampling location in a mine, etc) are given in column $\mathrm{H}$. Where available, descriptions of the analysed sample are given in column I.

\section{B.3 Sample medium, laboratory and method}

Column $\mathrm{J}$ qualitatively indicates the sample medium. Where available, relative abundances of minerals within the analysed sample are indicated; analysis of geochemical powders without specific mineral abundances is also indicated in this column. Column $\mathrm{K}$ indicates the relative abundance of lead in the samples. Samples were interpreted as $\mathrm{Pb}$-rich if either the sample medium contained significant quantities of galena or other $\mathrm{Pb}$-rich minerals, or if geochemical analyses of rock powders indicated $\mathrm{Pb}$ contents above $1000 \mathrm{ppm}$. In all other cases, including cases where mineralogical or geochemical details are unknown, the sample is assumed to be $\mathrm{Pb}$-poor.

Columns $L$ to $M$ indicate the laboratory at which the analysis was undertaken, the method, and the relative precision. Laboratories from which most of the data were sourced include CSIRO and the University of Melbourne (UMel). Other laboratories include Australian National University (ANU), Curtin University (Curtin), Latrobe University (Latrobe), the University of Alberta (UAlb) and the 
Table B1 Description of data included in Appendix A.

\begin{tabular}{|c|c|c|}
\hline Data type & $\begin{array}{l}\text { Column } \\
\text { header } \\
\text { (Column) }\end{array}$ & Description \\
\hline \multirow[t]{5}{*}{ Location data } & Deposit (A) & $\begin{array}{l}\text { Most commonly used name of deposit, prospect or occurrence (synonyms } \\
\text { are included in parentheses) }\end{array}$ \\
\hline & Lens (B) & Name of lens, if defined \\
\hline & State $(C)$ & Name of State/Territory where the deposit is located \\
\hline & Longitude (D) & Longitude of deposit/sample (GDA94 datum) \\
\hline & Latitude (E) & Latitude of deposit/sample (GDA94 datum) \\
\hline \multirow{4}{*}{$\begin{array}{l}\text { Sample name } \\
\text { and description }\end{array}$} & GA_ID (F) & Geoscience Australia sample identification \\
\hline & Other_ID (G) & Other sample identification \\
\hline & Location $(\mathrm{H})$ & $\begin{array}{l}\text { Location within deposit at which sample was collected. For drill holes, the } \\
\text { hole identification is followed by an @ and then by the depth (range). If units } \\
\text { are not indicated, the depth is in metres }\end{array}$ \\
\hline & Descrip (I) & Brief description of sample, if available \\
\hline \multirow{5}{*}{$\begin{array}{l}\text { Sample medium, } \\
\text { laboratory and } \\
\text { method }\end{array}$} & Medium (J) & Description of sample, including relative abundance of minerals analysed \\
\hline & Sam_type (K) & $\begin{array}{l}\text { Relative abundance of lead. If sample has visible lead minerals, or contains } \\
\text { over } 1000 \mathrm{ppm} \mathrm{Pb} \text { it is "Pb-rich". If has less than } 1000 \text { ppm or no information } \\
\text { on lead content is available the sample is "Pb-poor". }\end{array}$ \\
\hline & Laboratory (L) & Laboratory at which analysis was undertaken \\
\hline & Method (M) & Method of analysis \\
\hline & Precision $(\mathrm{N})$ & Relative precision of analytical method (low or high) \\
\hline \multirow[t]{7}{*}{ Measured results } & $\begin{array}{l}\text { Me_206-204 } \\
\text { (O) }\end{array}$ & Measured ${ }^{206} \mathrm{~Pb} /{ }^{204} \mathrm{~Pb}$ ratio \\
\hline & $\begin{array}{l}M e \_207-204 \\
(P)\end{array}$ & Measured ${ }^{207} \mathrm{~Pb} /{ }^{204} \mathrm{~Pb}$ ratio \\
\hline & $\begin{array}{l}\text { Me_208-204 } \\
\text { (Q) }\end{array}$ & Measured ${ }^{208} \mathrm{~Pb} /{ }^{204} \mathrm{~Pb}$ ratio \\
\hline & Q_factor (R) & $\begin{array}{l}\text { Quality factor for CSIRO analyses on a scale of } 0 \text { to } 9 \text {. Low scores indicate } \\
\text { high quality analyses; high scores indicate low quality analyses. The field is } \\
\text { left blank for non-CSIRO analyses or for CSIRO analyses where this } \\
\text { information is not available. }\end{array}$ \\
\hline & ${ }^{238} U_{(\mathrm{S})}(\mathrm{ppm})$ & Measured concentration of ${ }^{238} U$ (in ppm) \\
\hline & $\left.{ }^{232} \mathrm{Th}(\mathrm{T}) \mathrm{ppm}\right)$ & Measured concentration of ${ }^{232} \mathrm{Th}$ (in ppm) \\
\hline & $\mathrm{Pb} \_(\mathrm{ppm})(\mathrm{U})$ & Measured concentration of lead (in ppm) \\
\hline \multirow{2}{*}{$\begin{array}{l}\text { Parameters } \\
\text { calculated from } \\
\text { measured results }\end{array}$} & Me_mod_age & $\begin{array}{l}\text { Model age (in Ma) calculated from mearsured ratios using the Cumming and } \\
\text { Richards (1975) evolution model }\end{array}$ \\
\hline & Me_mu (W) & $\begin{array}{l}\mu \text { value calculated from mearsured ratios using the Cumming and Richards } \\
\text { (1975) evolution model }\end{array}$ \\
\hline \multirow[t]{2}{*}{$\begin{array}{l}\text { Estimated age of } \\
\text { mineralisation }\end{array}$} & Age $(X)$ & $\begin{array}{l}\text { Estimated age of mineralisation (in Ma) determined from published ages or } \\
\text { inferred geologically }\end{array}$ \\
\hline & Age_type (Y) & $\begin{array}{l}\text { Indicates if the age of mineralisation is constrained by geochronological data } \\
\text { (including faunal assemblages) or inferred from regional geological }\end{array}$ \\
\hline
\end{tabular}




\begin{tabular}{|c|c|c|}
\hline \multirow[t]{2}{*}{ Data type } & $\begin{array}{l}\text { Column } \\
\text { header } \\
\text { (Column) }\end{array}$ & Description \\
\hline & & relationships or correlations. \\
\hline \multirow[t]{4}{*}{ Initial ratios } & In_ratio $(Z)$ & $\begin{array}{l}\text { Toggle (yes/no: } Y / N \text { ) for each analysis identifying if the analysis can be used } \\
\text { to calculate initial ratios. Measured ratios of lead-rich samples are } \\
\text { considered to be initial ratios. Initial ratios can be calculated from lead-poor } \\
\text { samples if } \mathrm{Pb}, \mathrm{U} \text { and Th concentrations and the age of mineralisation are } \\
\text { known. Initial model ages and initial values are only calculated using ratios } \\
\text { that are considered initial. }\end{array}$ \\
\hline & $\begin{array}{l}\text { In_206-204 } \\
\text { (AA) }\end{array}$ & $\begin{array}{l}\text { Initial }{ }^{206} \mathrm{~Pb} /{ }^{204} \mathrm{~Pb} \text { ratio estimated from measured }{ }^{206} \mathrm{~Pb} /{ }^{204} \mathrm{~Pb} \text { ratio, measured } \\
\mathrm{U} \text { and } \mathrm{Pb} \text { contents, and mineralisation age using equation (1) }\end{array}$ \\
\hline & In_207-204 & $\begin{array}{l}\text { Initial }{ }^{2076} \mathrm{~Pb} /{ }^{204} \mathrm{~Pb} \text { ratio estimated from measured }{ }^{207} \mathrm{~Pb} /{ }^{204} \mathrm{~Pb} \text { ratio, } \\
\text { measured } \mathrm{U} \text { and } \mathrm{Pb} \text { contents, and mineralisation age using equation (2) }\end{array}$ \\
\hline & $\begin{array}{l}\text { In_208-204 } \\
(A C)\end{array}$ & $\begin{array}{l}\text { Initial }{ }^{208} \mathrm{~Pb} /{ }^{204} \mathrm{~Pb} \text { ratio estimated from measured }{ }^{208} \mathrm{~Pb} /{ }^{204} \mathrm{~Pb} \text { ratio, measured } \\
\text { Th and } \mathrm{Pb} \text { contents, and mineralisation age using equation (3) }\end{array}$ \\
\hline $\begin{array}{l}\text { Identification of } \\
\text { least radiogenic } \\
\text { analyses }\end{array}$ & Least_ra (AD) & $\begin{array}{l}\text { Toggle (yes } / \mathrm{no}: \mathrm{Y} / \mathrm{N} \text { ) for each deposit identifying which analysis is least } \\
\text { radiogenic. Least radiogenic analyses from each deposit were used during } \\
\text { contouring of various parameters }\end{array}$ \\
\hline \multirow{3}{*}{$\begin{array}{l}\text { Parameters } \\
\text { calculated from } \\
\text { initial ratios }\end{array}$} & $\begin{array}{l}\text { In_mod_age } \\
(A E)\end{array}$ & $\begin{array}{l}\text { Model age (in Ma) calculated from initial ratios using the Cumming and } \\
\text { Richards (1975) evolution model }\end{array}$ \\
\hline & In_mu (AF) & $\begin{array}{l}\mu \text { value calculated from initial ratios using the Cumming and Richards (1975) } \\
\text { evolution model }\end{array}$ \\
\hline & Delta_t (AG) & $\begin{array}{l}\text { Age difference (in Myr) between mineralisation age and initial model age } \\
\text { calculated using Cumming and Richards (1975) evolution model }\end{array}$ \\
\hline Comments & $\begin{array}{l}\text { Comments } \\
\qquad(\mathrm{AH})\end{array}$ & $\begin{array}{l}\text { Comments relevent to each analysis. Information included can include that } \\
\text { multiple analyses were averaged to produce cited analysis, or that analyses } \\
\text { were excluded for various reasons. In a few cases, poor quality analyses } \\
(\mathrm{Q}=7-9) \text { are included in the dataset if higher quality analyses were not } \\
\text { available for the sample. Such instances are also indicated in the comments. }\end{array}$ \\
\hline Source of data & Source (Al) & $\begin{array}{l}\text { The source of the analysis is indicated in this column. Most analyses are } \\
\text { from three datasets containing CSIRO data: CSIRO southeast Australia, } \\
\text { CSIRO north Queensland and ISOTAS. Other sources are cited according to } \\
\text { presentation in the literature. The citations are included as a separate } \\
\text { worksheet in the workbook. }\end{array}$ \\
\hline
\end{tabular}

University of Queensland (UQId). Analytical methods include conventional thermal ionisation mass spectropy (TIMS), double spike TIMS (DS-TIMS), and multi-collector induction-coupled-plasma mass spectrometry (MC-ICP-MS). Thermal ionisation mass spectrometry has low precision, whereas the other two methods have relatively high precision (column $\mathrm{N}$ ).

\section{B.4 Measured results}

Columns O through $\mathrm{Q}$ give lead isotope ratios $\left({ }^{206} \mathrm{~Pb},{ }^{207} \mathrm{~Pb}\right.$ and ${ }^{208} \mathrm{~Pb}$ normalised to $\left.{ }^{204} \mathrm{~Pb}\right)$, mostly to three decimal places. In cases where the results are approximate the values are given to two decimal places. Column R indicates the value of the CSIRO $Q$ factor, where available. Columns $S$ to $U$ give geochemical analyses of $\mathrm{U}, \mathrm{Th}$ and $\mathrm{Pb}$ (determined in most cases using ICP-MS). 


\section{B.5 Parameters calculated from measured results}

Columns $\mathrm{V}$ and $\mathrm{W}$ indicate model ages and $\mu$ calculated from measured data using the Cumming and Richards (1975) model and equations (4) and (5).

\section{B.6 Estimated age of mineralisation}

Column X indicates an estimate of the age of mineralisation determined either from published ages (cf. Huston et al. (2016b) for compilation) or inferred either from geological relationships or analogies with deposits of known ages. Inferred ages were established in consultation with Mineral Resources Tasmania, the Geological Survey of Victoria, the Geological Survey of New South Wales, the Geological Survey of Queensland, Klondyke Exploration and TerraSearch. Column Y gives the type of age, whether constrained by geochronological data or inferred from geological relationships and/or correlation.

\section{B.7 Initial ratios}

Columns $Z$ is a Yes/No toggle identifying analyses for which initial ratios can be estimated. Columns AA to AC present estimates of initial ratios for ${ }^{206} \mathrm{~Pb} /{ }^{204} \mathrm{~Pb},{ }^{207} \mathrm{~Pb} /{ }^{204} \mathrm{~Pb}$ and ${ }^{208} \mathrm{~Pb} /{ }^{204} \mathrm{~Pb}$. For samples which are considered $\mathrm{Pb}$-rich the measured ratios are taken as the initial ratios. For $\mathrm{Pb}$-poor samples for which ${ }^{238} \mathrm{U} /{ }^{204} \mathrm{~Pb}$ and/or ${ }^{232} \mathrm{Th} /{ }^{204} \mathrm{~Pb}$ ratios have been measured or can be reliably calculated and which an age of mineralisation can be reliably estimated, initial ratios have been calculated using equations (1) through (3).

\section{B.8 Least radiogenic ratios}

As many of the deposits in Appendix A are characterised by multiple analyses, the analysis used for contouring was selected based upon the following criteria. For deposits and prospects in which initial ratios were estimated, only the analyses for which these ratios are available were considered. In cases where initial ratios were not available all analyses were considered. In all cases, least radiogenic analyses were determined as those that yielded the youngest model ages (as calculated using the Cumming and Richards (1975) model). Column AD is a Yes/No toggle indicating which analyses for each deposit are considered least radiogentic. Values of $\mu$ and $\Delta t$ from these least radiogenic analyses were used in countouring the data.

\section{B.9 Parameters calculated from initial ratios}

Columns $A E$ and $A F$ indicate model ages and $\mu$ calculated from initial ratios using the Cumming and Richards (1975) model and equations (4) and (5). Where true age estimates (column X) and model ages (column $A E$ ) are available, differences in these ages ( $\triangle \mathrm{t}$ : column AG) were calculated using equation (6).

\section{B.10 Comments and references}

The final two columns ( $\mathrm{AH}$ and $\mathrm{Al}$ ) in the dataset highlight additional comments related to individual analyses and indicate the sources of the data. Characteristics noted in the comments include the averaging of multiple analyses from the same sample, exclusion of some multiple analyses during 
averaging, cases where analytical data was estimated from published graphs as opposed to tabulated data and other additional information regarding the analysed sample. Most data in this compilation are derived from three unpublished compilations of CSIRO data: southeast Australia, North Queensland and ISOTAS. Where the data are from the scientific literature, appropriate references are cited, and full references are given in the second tab of the Excel workbook. New data presented in this study are cited as "this study". 